Revista Iberoamericana, Vol. LXXX, Núm. 247, Abril-Junio 2014, 433-468

\title{
AGARRAR EL CAÑO DESINFLADO EN LA EYACULADA GUERRA. NOTAS SOBRE LAS CRÓNICAS DE PEDRO LEMEBEL EN LOS AÑOS NOVENTA
}

\author{
POR \\ Gonzalo Oyola ${ }^{1}$ \\ Universidad Nacional de La Plata
}

Andrea Cucatto in memoriam

Una aclaración previa. Estas notas intentan situar las crónicas de Pedro Lemebel en su emergencia, en el momento cuando la actualidad que define el género convierte los textos en intervenciones sobre su presente; pretenden visualizarlas en los comienzos. Edward Said (Begginings) ha señalado que en todo comienzo literario se establecen e imaginan relaciones entre diferentes sujetos, y se marca un punto de (dis)continuidad respecto de lo preexistente, que presenta la forma de relaciones de permanencia, antagonismo, o un cruce de ambas posibilidades. Los términos e ideas que convoca el concepto de "comienzo" (innovación, novedad, originalidad, cambio, convención, revolución, influencia, tradición), sigue Said, remiten a la inconclusividad de la historia que cuestiona la idea de origen: sólo hay espacios no lineales y tiempos espiralados. Lo que Said piensa hacia el interior de la serie literaria revela además que los comienzos rediseñan y redistribuyen cuerpos, deseos, discursos, objetos, textos, liberando la energía política del acto de enunciación; y cuando se trata de escrituras permiten interrogar su posibilidad de relación con algo diferente de ellas mismas. En esta dirección interpelo los textos, porque me interesa capturar algo de sus sentidos en la posdictadura chilena. Se trata entonces de afirmaciones y conjeturas que, como todo lo que se viene escribiendo sobre Pedro Lemebel, deberán revisarse al volver a pensar su producción en términos de sus nuevos vínculos mediáticos y editoriales, de la sociabilidad en espacios más institucionales del campo artístico-literario, de la imagen de escritor que desarrolló en los años 2000. Pero todavía es necesario volver a leer estos textos en sus comienzos,

1 Agradezco a Hernán Laufer, Fabiana Cantilo y Felipe Mitre, de quienes aprendo en sus modos de interrumpir, detener, desafiar las lenguas mayores. A Teresa Basile, por su solidez que me propone un diálogo exigente. A Beatriz Sarlo, que nos enseñó a quienes crecimos en la última dictadura argentina la lección ética del trabajo intelectual riguroso y comprometido. 
que tuvieron como presente otro comienzo: el del proceso de la transición democrática en Chile, hacia fines de la década de 1980.

\section{LA EYACULADA GUERRA}

A través de la imposición de una cultura del miedo enlazada al neoliberalismo económico, ${ }^{2}$ la dictadura de Pinochet “no sólo destruyó, materialmente, la regularidad del orden social y político que sustentaba la tradición democrática en Chile”, sino también desencadenó "una sucesión de quiebres y rupturas en todo el sistema de categorías que, hasta 1973, formulaba una determinada comprensión de lo social basada en reglas de inteligibilidad compartidas" (Richard, "Las marcas” 169). La maquinaria dictatorial proyectó sobre la sociedad chilena una discursividad que, asentada en una paradoja siniestra, apeló a "una racionalidad constructiva para disfrazar mejor la arbitrariedad de sus cortes de violencia destructiva” (Richard, “Destrucción” 31). En los enunciados del poder de facto, el golpe de 1973 aparecía como un gran acto ordenador que era actualizado una y otra vez en el constante llamado a la ciudadanía a integrarse a la normalización sobre un catálogo de valores permanente e inmutable, orientado a la uniformidad. Las divisiones entre "un nosotros y los otros, puros e impuros, patriotas y extremistas dio inicio al monótono y sostenido binarismo mediante el cual se regimentaron los cuerpos", convertidos en "un trágico territorio modélico de disciplinamiento" que "se hizo primordial a través de la tortura, el crimen y la desaparición” (Eltit, “Las dos caras” 18).

El discurso de la dictadura figuró el quiebre de la normalidad constitucional como un acto de fundación, y la violencia estatal fue disfrazada de resguardo de la paz social. El autoritarismo "se incrustaba en una ciudad configurada por nuevos signos

2 Chile fue escenario del primer experimento a nivel mundial de formación de un Estado neoliberal, tras el golpe de Pinochet. Hacia 1973, las políticas de sustitución de importaciones que habían regido los intentos de recuperación de las economías latinoamericanas cayeron en el desprestigio, y en Chile ése fue el momento de la irrupción de un nuevo modelo (Harvey) que derivó de una sistemática transferencia ideológica desde los Estados Unidos, a partir de la década de 1950. La Escuela de Chicago sostuvo que la pobreza del mundo subdesarrollado se debía a su falta de recursos humanos capaces de interpretar y conducir la economía, y no al orden internacional que promovía la dependencia económica y el intercambio desigual. Con el golpe del 11 de septiembre de 1973, este modelo se injertó de modo premeditado como un cuerpo extraño a la realidad chilena, y se hizo cargo de la conducción de los destinos económicos, implementando un sistema de libre mercado, con la privatización de los activos públicos, la flexibilización laboral, la apertura de los recursos naturales a la explotación privada, y la estimulación de inversiones extranjeras directas. (Harvey). El nuevo esquema económico impactó de manera brutal sobre los imaginarios sociales y políticos chilenos, suprimiendo la idea de bien común y estableciendo como absolutas las reglas del mercado que impusieron una concepción individualista de la sociedad (Muñoz 18). De este modo, el implante de un sistema económico sin filiaciones en la experiencia chilena y la espectacular violencia del terrorismo de Estado quebraron las continuidades históricas, despojando a los sujetos de sus esquemas de referencia.

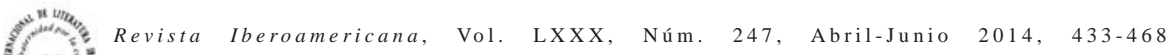
ISSN 0034-9631 (Impreso) $\quad$ ISSN 2154-4794 (Electrónico) 
que pregonaban una refundación nacional”, “obligatoria y selectiva que [...] miraba de manera absorta los cuerpos y los ponía bajo el microscopio del procedimiento militar” (Eltit, “Las dos caras” 20). Frente a esto, las víctimas fueron aprendiendo “a disputarle sentidos al habla oficial, hasta lograr rearticular las voces disidentes en microcircuitos alternativos” (Richard, “Destrucción” 29). Se produjo así una fuerte polarización ideológica entre “oficialidad (la integración al lenguaje de ‘modernización represión’ del gobierno militar) y no oficialidad (la lucha contra el paradigma dictatorial)” (Richard, “Destrucción” 29). En este marco, y ante la gran dureza represiva del régimen, las prácticas artísticas e intelectuales se replegaron a un espacio de semiclandestinidad. ${ }^{3}$ Pero a pesar de las maniobras totalizadoras de la dictadura, morosamente comenzaron a abrirse en su discurso fisuras que fueron aprovechadas por la oposición para intentar la ocupación de espacios de mayor visibilidad pública, dándose entonces “el tránsito de la ‘cultura contestataria’ a la ‘cultura alternativa”, el paso de un modo cultural orientado a la supervivencia política a otro “ya capaz de delimitar la especificidad de campos más autónomos y diferenciados de lenguajes”, si bien “el temario ideológico de la izquierda tradicional siguió privilegiando aquellos mensajes más directos que le servían eficazmente de propaganda en la lucha por la recuperación democrática” (Richard, “Destrucción” 32). En este punto, la izquierda en Chile acusó la conmoción de su circunstancia perturbada por la dictadura, pero también por la crisis política y teórica que a nivel internacional enfrentaba el marxismo histórico. Tales cimbronazos bifurcaron la izquierda chilena en una tendencia ortodoxa (que conservó la matriz clásica del marxismo-leninismo) y otra línea renovada más orientada hacia el socialismo. Esta división hablaba de dos direcciones en los planteamientos políticos, pero también identificó dos modos diferentes para las prácticas culturales y artísticas. La izquierda tradicional siguió pensando la cultura como una dimensión subordinada y determinada por la praxis política, mientras la izquierda renovada visualizaba tramas más complejas en esta relación. La izquierda tradicional reclamaba al arte una función concientizadora y una convicción militante que debía dar la voz a la clase obrera, único agente posible de la transformación social. Con una mirada

\footnotetext{
3 "El régimen de Pinochet nunca creó intelectuales orgánicos, a no ser que consideremos intelectuales a los monologadores histéricos sobre Dios, la familia y la tradición, o aun a los funcionarios técnicos importados de Chicago a partir del final de los 1970. [...] El estado dictatorial chileno operaría culturalmente a través de la imposición de una verdadera pasión por el consumismo, privatización absoluta de la vida pública, obsesiones con el éxito individual y horror por la política y la iniciativa colectiva [...]. La esfera cultural presenció la retirada del estado de su papel anterior de patrocinador. En lugar de él, pasaron a operar las fundaciones privadas con el propósito de mejorar la imagen pública de sus respectivas corporaciones a través de la promoción de becas y concursos. El edificio ideológico oficial, sin embargo, funcionaría primordialmente a través de los medios de comunicación. [...] Las nuevas condiciones forzaron a las producciones culturales no oficiales a debatirse entre la institucionalización y la marginalidad; la necesidad de ruptura política y simbólica y la necesidad paralela, a menudo contradictoria, de una interlocución social a un nivel más amplio” (Avelar 37-38).
}

Revista Iberoamericana, Vol. LXXX, Núm. 247, Abril-Junio 2014, 433-468
ISSN 0034-9631 (Impreso) 
antidogmática, la nueva izquierda alentó otro tipo de discursos estéticos, caracterizados "por extremar su pregunta en torno a las condiciones límite de la práctica artística en el marco totalitario de una sociedad represiva” y por "reformular el nexo entre 'arte' y 'política' fuera de toda dependencia ilustrativa al repertorio ideológico de la izquierda”, pero oponiéndose además "al idealismo de lo estético como esfera desvinculada de lo social y exenta de responsabilidad crítica en la denuncia de los poderes establecidos" (Richard, "Márgenes” 14). Se articuló así un espacio de prácticas estéticas en las que "el cuerpo expuesto podía representar y denunciar los atropellos de la dictadura” (Lemebel, Loco 39), oponiendo una pluralidad de voces y sentidos múltiples al discurso monológico y unidireccional del Estado autoritario, pero también disputando significados a "un cierto reduccionismo ideológico de la cultura militante que quería traducir y reducir el arte al realismo social de la contingencia” (Richard, "Márgenes" 25).

Hacia fines de la década de 1970 la escalada represiva del Estado terrorista alcanzó su intensidad máxima, y a comienzos de la década de 1980 la crisis económica chilena se había agudizado al punto de que sus índices de desocupación rondaban el veinte por ciento. Entre 1983 y 1987 hubo una serie de protestas nacionales, y por primera vez la dictadura pinochetista se enfrentó a acciones populares que desbordaron su esquema de dominio. ${ }^{4}$ Muchos analistas consideran 1986 un año decisivo para el inicio de la salida democrática: fue el año de la fallida emboscada del Frente Patriótico Manuel Rodríguez contra Pinochet; además, a fines de ese año, y de acuerdo con el programa previsto en la Carta Constitucional que el gobierno de facto se había dado, debía convocarse un plebiscito que decidiera su continuidad en el poder. Con la consulta popular en el horizonte, las fuerza políticas que convergerían en la futura Concertación trabajaron con la esperanza de enfrentar el régimen con la movilización ciudadana. Tras el triunfo del NO a Pinochet en el plebiscito, se intensificaron las negociaciones de los partidos de la coalición opositora conviniendo la candidatura de Patricio Aylwin, que llegó a la presidencia de Chile en marzo de 1990 con el cincuenta y cuatro por ciento de los votos.

En general, se nombra como "transición" el período que, iniciado en torno al plebiscito de 1988, hizo posible la salida hacia la democracia institucional. Sin

\footnotetext{
4 “La represión política alcanzó su auge en 1978-9, preparando el camino para la victoria de Pinochet en el plebiscito constitucional de 1980. De forma paralela a esta escalada, sin embargo, la sociedad civil reemerge lentamente de la derrota. 1983 marca una ruptura importante: los exiliados comenzaron a regresar, se levanta la censura de libros, 200.000 personas se concentran en las calles para conmemorar el décimo aniversario de la muerte de Pablo Neruda, y una vigorosa secuencia de protestas culmina en la Huelga General convocada por la Confederación de Trabajadores del Cobre en mayo de 1983. Hasta 1987 se llevaron a cabo alrededor de veinte ‘jornadas de protesta’ de un día de duración, sobre todo en Santiago. [...] Las protestas alcanzan mayor fuerza en las poblaciones, zonas pobres donde los trabajadores llegan a levantar barricadas y enfrentan una violenta represión, en un episodio luego conocido como la revuelta de los pobladores” (Avelar 38).
}

Revista Iberoamericana, Vol. LXXX, Núm. 247, Abril-Junio 2014, $433-468$
ISSN 0034-9631 (Impreso) 
embargo, Nelly Richard advierte que "los rasgos predominantes del período chileno llamado ‘transición' se formularon con anterioridad a este corte” y "los gobiernos de la transición democrática se dedicaron sobre todo a reagenciar la continuidad de los efectos ya delineados por la ofensiva neoliberal de la dictadura que conjugó represión (la violencia militar) con modernización (las políticas de consumo del mercado y la televisión)” (“La problemática” 227). Mercado y consenso fueron las instancias propuestas como soportes de la normalización social e institucional, formulándose una “democracia de los acuerdos” que marcó “el paso de la política como antagonismo [...] a la política como transacción: la fórmula del pacto y su tecnicismo de la negociación” (Richard, “La cita” 133). La alianza entre consenso y mercado disimuló los conflictos y disolvió la movilización social, promoviendo políticas que inducían al olvido del pasado reciente, con los medios de comunicación entre sus principales operadores. ${ }^{5}$ Se generó así una “democracia de baja calidad” (Garretón 14) que mantuvo vivas las herencias de la dictadura al conjugar "sus fórmulas de democratización institucional con un régimen intensivo de neoliberalización económica, para uniformar así un paisaje donde los acentos de lo político-ideológico se disolvieron en la masa de lo publicitario y lo mediático” (Richard, “Memoria” 29).

Las políticas del acuerdo desplegaron un modelo que, sostenido y divulgado por los medios, deportó “a las producciones críticas y a las estéticas no oficializables hacia los bordes del proyecto hegemónico” (Eltit, “La compra” 24), y promovió un relativismo valorativo impulsado por el mercado, que diluía la potencia conflictiva y polémica de las diferencias ${ }^{6}$ cuya diversidad debía ser "regulada por los pactos de entendimiento y negociación que estaban destinados a contener sus excesos", "para controlar la pluralidad heterogénea de lo social” (Richard, “La cita” 134). El pacto entre el mercado y las políticas del consenso desechó de su espacio todo aquello que no se enmarcara en los significados convenidos, y descartó todo lo disfuncional a su economía (discursiva), produciendo una masa de residuos subjetivos y culturales no reciclables en su máquina de indiferenciación de las diferencias. Se instauró "la transparencia sociocomunicativa que, en nombre del realismo instrumental del consenso, trata de limar las asperezas

5 “Durante los años de la transición democrática en Chile, la prensa y la televisión desviaron expresamente la mirada de las imágenes que recordaban los violentos hechos de la dictadura, para que las cargas de enfrentamientos -aún depositada en su pasado de discordias- no chocara con la retórica naturalizadora y homogeneizadora del consenso que selló la 'democracia de los acuerdos”” (Richard, "La historia contándose” 197).

6 "En nombre del relativismo valorativo, y a falta de otros criterios de diferenciación porque precisamente son los fundamentos del valor los que han sido erosionados, se opera como si el mercado fuera el espacio ideal del pluralismo. Aunque también podría pensarse que más que neutralidad valorativa lo que el mercado ejerce son fuertes intervenciones sobre los artistas y sobre el público. [...] El pluralismo y la neutralidad valorativa [...] no significan lo mismo en la esfera del arte que en la perspectiva desde la que se juzgan las diferencias entre los pueblos o las costumbres” (Sarlo, "El relativismo” 31).

\footnotetext{
Revista Iberoamericana, Vol. LXXX, Núm. 247, Abril-Junio 2014, 433-468 ISSN 0034-9631 (Impreso) ISSN 2154-4794 (Electrónico)
} 
de la superficie demasiado pulida en la que brillan los signos del acuerdo" (Richard, "Roturas" 114).

En este contexto Pedro Lemebel comenzaba a trabajar en la crónica, proponiendo una escritura que invistió de potencia simbólica residuos de los discursos del consenso, al reinscribirlos en una superficie donde se hacía posible la expansión de sus densidades semánticas configuradas en la historia. El texto lemebeliano fue dis-funcional e intraducible a los acuerdos discursivos generados en el Chile de la transición democrática, porque exhibía pérdidas que el acuerdo necesitaba desdeñar para desactivar el conflicto ideológico que las diferencias instalan como lucha de valores. Pero, además, la escritura de Lemebel también propuso una alternativa de sentido a las miradas totalizadoras de la cultura militante y su estética realista-romántica, ${ }^{7}$ interrumpiendo la totalización al subrayar las tensiones en el interior de sus imágenes. Las crónicas se embadurnaron con desechos desplegando su poética neobarrocha como un régimen de intensidades que fragmentó las narraciones lineales de la memoria y del presente produciendo, como quería Walter Benjamin, un relato discontinuo para la historia de los oprimidos.

\section{Agarrar el caño desinflado}

¿Van a dejarnos bordar de pájaros las banderas de la patria libre? Pedro Lemebel

En la década de 1990 Pedro Maradones, en fuga hacia lo materno se nombró Pedro

\footnotetext{
7 Beatriz Sarlo ha trabajado la idea de una estética realista-romántica en los relatos (en general cercanos al testimonio) de la cultura militante: “[...] el discurso de la memoria y las narraciones en primera persona se mueven por el impulso de cerrar los sentidos que se escapan; no sólo se articulan contra el olvido, también luchan por un significado que unifique la interpretación. [...] En el límite está la utopía de un relato 'completo', del cual no quede nada afuera. La inclinación por el detalle y la acumulación de precisiones crea la ilusión de que lo concreto de la experiencia pasada quedó capturado en el discurso. [...] tanto la adjudicación de un sentido único a la historia, como la acumulación de detalles, producen un modo realista-romántico, en el cual el sujeto que narra atribuye sentidos a todo detalle por el hecho mismo de que él lo ha incluido en su relato; $y$, en cambio, no se cree obligado a atribuir sentidos, sino a explicar las ausencias [...]" (Tiempo 67-68); "Todo puede ser falso en un testimonio menos los detalles. No digo que todo sea falso en estos testimonios. Digo simplemente, que el efecto de verdad del testimonio depende de esos, amontonados y repetidos [...]. [...] La verdad está en el detalle, y sobre todo en la repetición casi del mismo corpus de detalles” (“Cuando la política” 16); "La cualidad romántica tiene que ver con [...] el centramiento en la primera persona, o en una tercera persona presentada a través del discurso indirecto libre que entrega al narrador la perspectiva de una primera persona. El narrador confía en la representación de una subjetividad y, con frecuencia, en su expresión efusiva y sentimental [...]" (Tiempo 75).

ISSN 0034-9631 (Impreso)
} 
Lemebel, ${ }^{8}$ y abandonó el género cuento para comenzar en la crónica. ${ }^{9}$ Estos dos cambios fueron movimientos enmarcados en la nueva visibilidad alcanzada por el escritor con su "Manifiesto (Hablo por mi diferencia)", ${ }^{10}$ intervención leída en un acto de la izquierda política en septiembre de $1986 .{ }^{11} \mathrm{El}$ cambio de nombre y de género textual se asociaron al manifiesto para fundar la posición de un sujeto que habla por y desde su diferencia, escribiendo el relato de la ocupación de un lugar enunciativo agenciado a las acciones por la visibilidad de las minorías sexuales, puestas en marcha por un colectivo alerta a las propuestas de algunos discursos intelectuales y también a las estrategias del mercado respecto de los cuerpos, deseos y espacios que ensayaban ser visibles.

Desde los años ochenta, una línea de los estudios latinoamericanos ha estado atenta a las redefiniciones de los vínculos entre el centro y la periferia, y a los problemas que teóricos como Gayatri Spivak, Edward Said y Homi Bhabha compusieron en sintonía con las preguntas sobre la diferencia y lo subalterno, que se habían hecho presentes con la crisis de la centralidad que la franja más nietzscheana del posestructuralismo francés propuso con distintas categorías. Las lecturas latinoamericanas más lúcidas advirtieron que estaba en juego "la pregunta por el valor -insurgente o rendido- de los nuevos cruces entre: marginalidad latinoamericana y defensa posmoderna de los márgenes” (Richard, "Periferias" 5). Pero la incorporación de estos problemas a las agendas también generó una oferta cultural formal e ideológicamente blanda con estos temas. El discurso universitario, por ejemplo, viene produciendo toda una biblioteca sobre otredad, subalternidad, diferencia, hibridez, diversidad, multiculturalismo, con algunas propuestas interesantes, y muchos trabajos que usan estas categorías sólo como herramientas de aplicación sobre objetos de baja densidad formal y semántica, garantizando entonces su circulación por un mercado académico celebratorio de las modas teóricas. Se ha ido formando así un discurso que hilvana un patchwork teórico sobre "la 'diferencia'

8 Loco afán, segundo libro de crónicas, está dedicado en primer lugar a “Olga Lemebel, mi abuela materna, madre soltera y ternura errante" y a "Violeta Lemebel, la mujer que me dio la voz".

9 "Muchos decían entonces que el Pedro Mardones del cuento era mi destino. Fíjate, creo que en ese momento -1986-1987- me empezó a cargar ese nombre legalizado por la próstata del padre. Tú sabes que en Chile todos los apellidos son paternos, hasta la madre lleva esa macha descendencia. Por lo mismo desempolvé mi segundo: el Lemebel de mi madre, hija natural de mi abuela, quien, al parecer, lo inventó jovencita cuando escapó de su casa [...] El Lemebel fue un gesto de alianza con lo femenino, inscribir un apellido materno, reconocer a mi madre huacha desde la ilegalidad homosexual y travesti" (Blanco 3-4, énfasis mío).

${ }^{10}$ El "Manifiesto" fue publicado después, en Loco afán. Crónicas del sidario (1996) segundo libro de crónicas de Lemebel.

11 “[...] al escribir un manifiesto sobre mi homosexualidad de alguna manera me inserté entre lo público en el año 87 más o menos. Creo que después de ese manifiesto, como que yo entendí lo que era la crónica. Como que en esta escritura que yo iba a desarrollar podía estar acentuado, por ejemplo, mi color sexual, por no decir elección sexual o qué sé yo, mi color sexual, color que puede ser tornasol” (López García 491).

Revista Iberoamericana, Vol. LXXX, Núm. 247,
ISSN 0034-9631 (Impreso) 
como festividad exótica” (Richard, "Periferias” 5), y que -integrado a los medios de comunicación y procesado por las zonas más complacientes de "lo subalterno"-, es agente de un sentido común que funciona de modo semejante al "orientalismo" que Said ha leído en las escrituras de los archivos coloniales producidos en las metrópolis (Orientalismo). En esta economía reflexiva, y pese a que las sexualidades disidentes latinoamericanas ganaron estatuto epistémico, la mayoría de los intelectuales y de los activistas fue lenta para percibir significados y problemas en los cambios veloces que la modernidad neoliberal imprimió a la socialización y el intercambio de las subjetividades periféricas. Se recibió entonces con beneplácito la mayor visibilidad obtenida, durante la década de 1980, por ciertos espacios de sociabilidad homoerótica en algunas capitales de América Latina, sin percibir que al mismo tiempo eran capturados como soportes del mercado para un nuevo público diferenciado. ${ }^{12}$ Con un imaginario muy impactado por la cultura audiovisual, la moda marcó los valores estableciendo jerarquías que operaron nuevas exclusiones separando "en estratificaciones de clase a locas, maricas y travestis de los acomodados gays en su pequeño arribismo traidor” (Lemebel, Loco 126). El mercado reorganizó valores, hábitos y modos de las conductas (que surgían de experiencias muy distintas) alrededor de las pautas del modelo identitario gay, ${ }^{13} \mathrm{e}$ inventó al ciudadano-consumidor homosexual. Para instalarse como modelo subjetivo, el ciudadano-consumidor gay buscó ser representado, y esto tal vez explique algunas alianzas con los medios de comunicación y el entusiasmo de los investigadores universitarios. Se perdió de vista que la demanda de representación es una delegación de la voz que desplaza para el “sujeto de esa ‘diferencia’ el derecho de autogestionar sus propias condiciones de manejo discursivo: a practicar su 'diferencia' en sentido -intervencionista- de rebeldía, disturbio frente a las significaciones prefijadas por el repertorio oficial de la 'diferencia”” (Richard, “Periferias” 5-6).

\footnotetext{
12 "La historia del capitalismo es una constante adaptación a las líneas de fuga incitadas por su propia naturaleza desterritorializada, moviéndose entre dos polos: «su polo de fuga y su polo de endurecimiento: Su polo de fuga consiste en la descodificación, en la desterritorialización completa de los flujos [...] pero al mismo tiempo hace un torniquete, realienando, volviendo a atar» (Deleuze), mediante la adición o sustracción de axiomas. Éstos pueden ser de cercamiento, desterritorialización, multicentralización o segmentariedad. Cada vez que distintas líneas de fuga amenazan con un agenciamiento colectivo que podría acabar en la destrucción del capital, éste reacciona incorporando la desterritorialización en ciernes y haciéndola pasar por el capital-dinero, su cuerpo sin órganos, convirtiéndola en una mercancía que le permita continuar extrayendo plusvalor maquínico" (Salazar 7).

13 "Hoy los parques de ligue han sido desplazados por los lugares del deseo gay como las discotecas, pub y saunas. Por lo que se puede señalar que las geografías del placer homoerótico han transitado desde un deseo disperso y heterogéneo a uno monolítico y unitario, atrapándonos en ghetos de vigilancias", Durán, M. "Michel Foucault y su política queer de los placeres. Una mirada de las geografías del deseo homoerótico en Chile”, Cyber Humanitis. Revista de la Facultad de Filosofía y Humanidades 35 (2005): 8, citado en Salazar.
}

Revista Iberoamericana, Vol. LXXX, Núm. 247, Abril-Junio 2014, $433-468$
ISSN 0034-9631 (Impreso) 
La enunciación de Lemebel emergió entonces en el presente de una esfera pública redefinida por la cultura mediática y los valores del mercado, con cierta tolerancia al ciudadano-consumidor gay pero que enviaba cualquier otro estado no canónico del género o del deseo a una galería de "casos" con su retórica de la vida marginal, y el "goteo de maricas charqueados por la tinta roja de algún diario, expuestos en su palidez de castigo como reiteración de las puñaladas en el borde plateado de costilla apátrida” (Lemebel, Loco 125-26). Lemebel trabajó con los residuos de este orden del discurso, haciendo reingresar las imágenes desechadas. El manifiesto y su enunciación produjeron una política de la estética en tanto "sus haceres moldean formas de visibilidad que reenmarcan el entretejido de prácticas, maneras de ser y modos de sentir y decir en un sentido común” (Rancière 13). Si, como ha sostenido Jacques Rancière discutiendo la lectura clásica de República de Platón, la política empieza “cuando aquellos que 'no tienen tiempo’ para hacer nada aparte de su trabajo toman ese tiempo que no tienen para hacerse visibles" (14), los movimientos que provocó Lemebel fueron políticos en tanto se agenciaron a una nueva "partición de lo sensible”, una nueva “distribución y redistribución de tiempos y espacios, lugares e identidades, [una nueva manera] de encuadrar y reencuadrar lo visible y lo invisible, de distinguir el habla del ruido" (14). ${ }^{14}$ La escritura de Lemebel venía a formar parte del sensorium que, durante los años de la década de 1980, conformó el campo de experiencias de la diversidad sexual como espacio político-estético, con la irrupción de formaciones como el Colectivo Feminista Lesbiano Ayuquelen fundado en 1984, el Movimiento de Liberación Homosexual (MOVILH) organizado en 1987, las intervenciones del colectivo de arte Yeguas del Apocalipsis (1988) integrado por Lemebel y Francisco Casas, la Editorial Cuarto Propio y la Radio Tierra.

La novedad de la forma de pensar lo político a la que se asocian las intervenciones estéticas y críticas de Lemebel se hace evidente al considerar algunas ideas sobre sexualidad y género, muy fuertes durante el período de la Unidad Popular. Margaret Power argumenta que en los setentas chilenos

[...] las ideas acerca del género eran a la vez omnipresentes e invisibles. Aunque permeaban y definían la mayoría de los aspectos de las relaciones sociales, permanecieron, en gran parte, ignoradas y supuestas. Lo anterior se debió a que, pese a las profundas diferencias políticas que marcaron a Chile durante esta época de intensa polarización

\footnotetext{
14 Jacques Ranciére piensa la politicidad del arte en virtud de la distancia respecto de las funciones comunicativas y representativas; el arte es político porque "enmarca no sólo las obras o monumentos, sino el sensorium de un espacio-tiempo específico, siendo que dicho sensorium define maneras de estar juntos o separados, de estar adentro o afuera, enfrente de o en medio de, etc." (13); "porque, la propia política no es el ejercicio del poder o la lucha por el poder. Antes que nada, la política es la configuración de un espacio como político, la delimitación de una esfera específica de experiencia, la delimitación de objetos planteados como 'comunes' y de sujetos a quienes se reconoce la capacidad de designar esos objetos y discutir sobre ellos” (13).
}

ISSN 0034-9631 (Impreso) 
en este aspecto, en las ideas acerca de lo que significaba ser hombre o mujer había un grado notable de consenso. (Power 251)

Así, el programa de transformación social puesto en marcha por el gobierno de Salvador Allende no contempló en las expectativas de cambio problemas referidos a temas de sexualidad y género, porque en esos puntos la Unidad Popular permaneció tan conservadora como la derecha. Sin embargo, Power señala que algún núcleo de la izquierda y sectores de la juventud chilena produjeron ideas más abiertas y progresistas; como Ramona, publicación de la Juventud Comunista donde se discutieron "tópicos como el control de la natalidad, la homosexualidad y la supremacía masculina” (Power 252). Con todo, el tono general fue machista y homofóbico. Malas lecturas de Engels, las izquierdas latinoamericanas tardaron demasiado en ver el vínculo estrecho entre capitalismo y orden patriarcal, aliados en un mismo modo de producción de bienes y subjetividades. El 22 de abril de 1973 se produjo la primera protesta homosexual en Chile, en la que unas cincuenta personas que no superaban los veinte años marcharon contra la represión policial. "Protestamos porque estábamos cansadas de la discriminación. En esos años, si andabas en la calle y los pacos se daban cuenta de que eras maricón, te llevaban preso, te pegaban y te cortaban el pelo por el sólo hecho de ser maricón. Las cárceles y las comisarías eran como hoteles para nosotras” (Robles 4), recuerdan sus protagonistas. La revista de orientación comunista Paloma habló de "50 anormales reunidos en Plaza de Armas” (Robles 4, énfasis mío). El Clarín, periódico cercano a la administración de la Unidad Popular, tituló “Colipatos piden chicha y chancho”, y en el artículo se leía: "Las yeguas sueltas, locas perdidas, ansiosas de publicidad, lanzadas de frentón, se reunieron para exigir que las autoridades les den cancha, tiro y lado para sus desviaciones. Pese a que la reunión había sido bastante publicitada, la policía no se hizo presente”; se caracterizaba además el objeto de la movilización: “Entre otras cosas, los homosexuales quieren que se legisle para que puedan casarse y hacer las mil y una sin persecución policial. La que se armaría. Con razón un viejo propuso rociarlos con parafina y tirarles un fósforo encendido". ${ }^{15}$ En la misma línea, la sección de policiales del mismo diario presentaba con frecuencia notas en las que los homosexuales aparecían ligados a crímenes y hechos de violencia: "Colipatos asesinan a machote por traidor"; 16 “¡Dos cabros pervertidos! Son los asesinos del profesor colipato y del taxista porteño”. ${ }^{17}$ En la compulsa política, la "presunción” de homosexualidad fue una estrategia utilizada tanto por la izquierda como por la derecha para impugnar al adversario; por ejemplo el candidato de la derecha en las elecciones de 1970, Jorge Alessandri Rodríguez, fue

${ }^{15}$ El Clarín, Santiago de Chile, 24 de abril de 1973, citado en Acevedo 7, énfasis mío.

${ }^{16}$ El Clarín, Santiago de Chile, 3 de enero de 1971, citado en Acevedo 7.

17 El Clarín, Santiago de Chile, 1 de junio de 1971, citado en Acevedo 7.

Revista Iberoamericana, Vol. LXXX, Núm. 247, Abril-Junio 2014, $433-468$
ISSN 0034-9631 (Impreso)


calificado como homosexual por su soltería en edad avanzada y apodado públicamente "La Señora". ${ }^{18}$

El referido trabajo de Margaret Power remarca que si bien la dirigencia de la Unidad Popular estuvo integrada en su mayoría por hombres de clase media, utilizó como símbolo las imágenes del "rudo y musculoso hombre trabajador: el minero, el obrero, el trabajador de la construcción”, convirtiéndolo en el protagonista de las luchas sociales “ya que era él quien tenía la fuerza para derrotar a la burguesía y la determinación para construir una sociedad socialista” (257-258). Lemebel retomó esta imagen de masculinidad presente en la Unidad Popular para sustraerla de su situación de discurso y hacerle movilizar otras significaciones. El "Manifiesto" es un texto que, marcado de modo fuerte por la función apelativa, convoca y configura como interlocutor al hombre heterosexual militante de la izquierda chilena. El texto despliega una cadena de preguntas retóricas que confrontan a su destinatario con experiencias de lo subalterno atravesadas por la categoría de la clase social (único espacio donde la izquierda del momento percibía la producción de desigualdad y dominio), pero que además la exceden: "Porque ser pobre y maricón es peor” (Lemebel, Loco 93). "Pobre” y “maricón” son categorías que demarcan la nueva partición de lo sensible donde se emplaza la subjetividad que enuncia en los textos de Lemebel. ${ }^{19}$ En "La noche de los visones (o la última fiesta de la Unidad Popular)", primer texto de Loco afán, aparece nítida la figura del "rudo y musculoso hombre trabajador" que la enunciación “coliza” de la crónica lemebeliana re-escribe:

Esas damas rubias que pedían a gritos un golpe de Estado, un cambio militar que detuviera el escándalo bolchevique. Los obreros las miraban y se agarraban el bulto ofreciéndoles sexo, riéndose a carcajadas, a toda hilera de dientes frescos, a todo viento libre que respiraban felices cuando hacían cola frente a la UNCTAD para almorzar. Algunas locas se paseaban entre ellos, simulando perder el vale de canje, buscándolo en sus bolsos artesanales, sacando pañuelitos y cosméticos hasta encontrarlo con

\footnotetext{
18 “Matones de 'La Señora' siembran el terror en poblaciones populares” tituló El Clarín el 2 de septiembre de 1970, citado en Acevedo 9.

19 "Porque ser pobre y maricón es peor / Hay que ser ácido para soportarlo / Es darle un rodeo a los machitos de la esquina / Es un padre que te odia / Porque al hijo se le dobla la patita / Es tener una madre de manos tajeadas por el cloro / Envejecidas de limpieza / Acunándote de enfermo / Por malas costumbres” (93); “¿Y usted? / ¿Qué hará con ese recuerdo de niños / Pajeándonos y otras cosas / En las vacaciones de Cartagena? / ¿El tiempo en noche y día laboral / sin ambigüedades? / ¿ No habrá un maricón en alguna esquina / desequilibrando el futuro de su hombre nuevo? / ¿Van a dejarnos bordar de pájaros / las banderas de la patria libre?” (94); "Y no se sienta agredido / Si le hablo de estas cosas / Y le miro el bulto / No soy hipócrita / ¿Acaso las tetas de una mujer / no le hacen bajar la vista? / ¿No cree usted / que solos en la sierra / algo se nos iba a ocurrir? / Aunque después me odie / Por corromper su moral revolucionaria / ¿Tiene miedo de que se le homosexualice la vida? / Y no hablo de meterlo y sacarlo / Y sacarlo y meterlo solamente / Hablo de ternura compañero / Usted no sabe / Cómo cuesta encontrar el amor / En estas condiciones / Usted no sabe / Qué es cargar con esta lepra” (95).
}

Revista Iberoamericana, Vol. LXXX, Núm. 247,
ISSN 0034-9631 (Impreso) 
grititos de triunfo, con miradas lascivas y toqueteos apresurados que deslizaban por los cuerpos sudorosos. (13)

El emblema de masculinidad de la Unidad Popular es presentado en una trama que lo sustrae del epos de la gesta revolucionaria para integrarlo a una imagen carnavalizada, donde las categorías sociales (clase, género, deseo) se desprenden de los relatos maniqueos de la izquierda. La escritura de Lemebel devuelve la corporalidad a la figura del "hombre nuevo”, revelándola como una superficie inundada por deseos. El carnaval lemebeliano no anula las jerarquías sociales; por el contrario, sus máscaras se dibujan sobre puntos de conflicto y tensión que definen las relaciones entre historia, política y deseo. Las locas de Lemebel se infiltran entre las burguesas "que odiaban a Allende y su porotada popular" (Loco 15) y los obreros, con su loco afán que perturba las disposiciones de los géneros y los deseos. Las locas de Lemebel, con su “folclor mariposón” (59), eligen los "músculos proletarios en fila” (13) y rechazan el "negocio de músculos transpirados” del "modelo Travolta sólo para hombres” de la identidad gay. Así, entonces, el comienzo que agencia la textualidad lemebeliana a una nueva partición de lo sensible produce un doble corte: con la tradición de la izquierda orotodoxa que, orientada sólo por la clase social, alentaba una masculinidad conservadora, por momentos reaccionaria; y con el presente del ciudadano-consumidor gay configurado por el mercado aliado de las políticas del Acuerdo.

2.

$$
\begin{aligned}
& \text {...las pequeñas y las grandes epopeyas nunca son } \\
& \text { paralelas... }
\end{aligned}
$$

Cambio de nombre y cambio de tipo textual (performativos que afectan los géneros) son gestos en los que puede leerse los temblores de una estética. Maradones se traviste de Lemebel fugando la identidad hacia lo materno, la oralidad, la etnia originaria: hacia lugares marcados por la pérdida y la derrota. La pérdida, señala Ana Amar Sánchez, es lo opuesto a la resignación: ser "perdedor" significa ejercer formas diversas de resistencia y triunfar superando la conformidad ante la derrota; de este modo, la pérdida se resignifica en la dimensión de un triunfo ético-político. Ahora bien, en Lemebel las ideas de pérdida y de derrota abarcan procesos más extensos que los que se recortan en una definición clásica de lo político, como los contextos posdictatoriales para los que Amar Sánchez imagina su "perdedor-ético". En la escritura de Lemebel, la pérdida y la derrota nombran lo des-hecho por los procesos de dominación, lo que falta en las lenguas de los vencedores, y entonces las dictaduras del Cono Sur aparecen como un eslabón reciente de la cadena de barbarie dominadora padecida desde la Conquista, y los desparecidos lo que falta por excelencia.

Revista Iberoamericana, Vol. LXXX, Núm. 247, Abril-Junio 2014,
ISSN 0034-9631 (Impreso) 
La textualidad lemebeliana expande una lengua que presenta su morfología y su sintaxis dislocadas respecto de la lengua-centro, y la vuelve "un brillo concheperla", "un guiño colifrunci" que "taconea el laburo filudo del alma ramera" (Lemebel, Loco 84). La escritura hace un pliegue en el orden del discurso, y se vuelve un habla desde la analidad y lo abyecto que minoriza la lengua-centro "aprovechando sus intervalos y silencios; entremedio y a medias, reciclando una oralidad del detritus como alquimia escretora que demarca en el goce esfinteral su crónica rosa” (124). La loca toma la voz y la enunciación deviene "mujer como toda minoría” (Lemebel cita a Deleuze); aprende "la lengua patriarcal para maldecirla", "parodiando su verticalismo" y oblicuándose "una vez más desde las peluquerías y barriales de la hermandad travesti” (124). Así, el "mariconaje guerrero" resiste la captura de los discursos mediáticos y de mercado "desde el borde de la voz de un discurso propio y fragmentado" y el "balbuceo de signos y cicatrices comunes" (127). Ese balbuceo (otra vez Deleuze) es la escritura lemebeliana: las cicatrices, marcas, trazas, huellas que iteran provocando la textualidad. En la incesante inscripción de cicatrices que señalan lo que ha sido amputado, la escritura revela que ningún contexto es saturable (Derrida), y yuxtapone materiales de diferentes espacios sociales que recicla cosiéndolos con sus propios desechos, para rearmar así las materialidades históricas (cuerpos, textos, discursos, deseos) de las subjetividades deshechas (Butler, Deshacer) ${ }^{20}$ Porque la escritura de Lemebel pone a circular los restos de subjetividades cuyos modos de estar en el mundo han sido des-hechos por concepciones normativas y modelos de la productividad moderna (y neoliberal, como su capítulo más reciente), que socavaron sus posibilidades de habitar una vida digna; sujetos, cuerpos, deseos rotos, como se nombra en Chile a las clases populares. En las crónicas, estos restos, marcas, cicatrices, trazas, huellas que conforman el balbuceo de las subjetividades des-hechas, instalan su iteración sobre otra cadena de signos, la semiosis de la sociedad neoliberal en la posdictadura chilena, con sus relatos mediáticos y de mercado. ${ }^{21} \mathrm{~A}$ contrapelo de las lenguas mayores de la sociedad posindustrial -controladas por la ley del Uno, de la totalidad que gobierna la multiplicidad-, el habla barrocha escribe lo que falta en los relatos del mercado, impregnándolos de signos -perlas (deformadas) y cicatrices- que se desmarcan de las normas de una blanda racionalidad comunicativa

20 “En algunas ocasiones una concepción normativa del género puede deshacer la propia persona al socavar su capacidad de continuar habitando una vida llevadera. En otras ocasiones, la experiencia de deshacer una restricción normativa puede desmontar una concepción previa sobre el propio ser con el único fin de inaugurar una concepción relativamente nueva que tiene como objetivo lograr un mayor grado de habitabilidad” (Butler, Deshacer 13).

21 "Una escritura itinerante del spray en mano, que marca su recorrido con la flechada gótica de los trazos. La gramática prófuga del graffiti que ejercita su letra porra rayando los muros de la ciudad feliz, la cara neoliberal del continente, manchada por el rouge negro que derraman los chicos de la calle" (Lemebel, La esquina 37, énfasis mío).

Revista Iberoamericana, Vol. LXXX, Núm. 247,
ISSN 0034-9631 (Impreso) 
orientada a fines de los años noventa en Chile. Es una escritura que nombra porque no muestra los residuos pidiendo para ellos una representación en los relatos de la esfera pública, sino que reclama y ejerce la voz que habla una lengua fragmentaria construida con desechos. Éste es un gesto fuerte que desafía las retóricas de la representación del ciudadano-consumidor gay con el balbuceo de una lengua mal-dicha (maldita), que hace audibles las fricciones, los roces entre la política, la historia y el deseo. La escritura nombra con una voz al límite del aullido, al límite de la disolución (habla disoluta) en los movimientos semióticos (Kristeva) ${ }^{22}$ de su materia significante. Estos cortes, estos pasajes de la lengua-centro por intensidades que la minorizan, hacen un trabajo con la palabra donde resuena el texto poético de quien tal vez sea la influencia intelectual más fuerte en Lemebel: Néstor Perlongher. ${ }^{23}$

Sin duda fue Perlongher quien primero percibió con claridad problemas y trampas en el modelo identitario gay. De manera precisa y temprana, incluso para el debate internacional, definió el modelo como una lengua cosificada y productora de un sentido común operador de nuevas exclusiones:

En principio, la idea de “identidad homosexual” sólo puede ser entendida desde la perspectiva del llamado "modelo igualitario", del cual es una de sus puntas de lanza. Su instauración no implicaría solamente un develamiento de las libidinidosidades constreñidas a una penumbra secular, sino que supondría una especie de traducción, como si las antiguas pasiones pudiesen, gracias a la versatilidad fundamental del deseo, ser vertidas en nuevos moldes. Operativo de “modernización” que, tras un período de festividad difusa, rápidamente recuperada por el consumismo de las modas y la industria del ocio, parece proceder a una redistribución de los enlaces homoeróticos, reagrupando a sus cultores en nuevas casillas de la identidad y -lo que es más grave-condenando a los practicantes de las viejas modalidades, las "homosexualidades populares”, a una creciente marginación capaz de alentar un recrudecimiento de la intolerancia popular hacia la nueva homosexualidad "blanqueada”, beneficiaria de la tolerancia burguesa. (Perlongher, La prostitución 98-99)

${ }^{22}$ Kristeva (La revolution) discute la idea lacaniana de que el acceso a la cultura necesita de la represión del vínculo primario con el cuerpo materno. Distingue entonces una dimensión semiótica del lenguaje, en tensión con lo simbólico como ley del padre. Lo semiótico se origina en el cuerpo materno y manifiesta la multiplicidad de la pulsión en los propios términos de la cultura, especialmente en el lenguaje poético. Lo semiótico recupera el cuerpo materno en el lenguaje, trastornando la ley paterna.

23 “Antes de entrar en la crónica tuve mucha relación con la poesía, con los poetas. Uno de los detonantes afectivos, emotivos más importantes para mí fue Nestor Perlongher. Con él encontré complejidades políticas, un lenguaje completo y complejo pero rico en fisuras. Creo que tuve un enamoramiento con él. Yo tuve con él primero un enganche como poeta más que con su trabajo crítico, específicamente con Cadáveres que es un poema grandioso, grandioso. Después vinieron sus textos teóricos” (Jeftanovic).

Revista Iberoamericana, Vol. LXXX, Núm. 247, Abril-Junio 2014, $433-468$
ISSN 0034-9631 (Impreso) 
La cita anterior pertenece a la tesis de doctorado que, a mediados de la década de 1980, Perlongher defendió en la Universidad de Campinas. En 1987 O Negócio do Michê. Prostitução Viril em São Paulo se publicó en Brasil, y apareció en Argentina como La prostitución masculina en 1993. Jorge Panesi ha leído este texto como "una poética del deseo homosexual” ("Marginales" 346) que expande el repertorio de ideas matriz del pensamiento y la obra de Perlongher: los desarrollos de Deleuze sobre la desterritorialización nómade, una línea de la literatura latinoamericana y el barroco “como síntesis del exceso, la superabundancia y el nomadismo del deseo" (Panesi 346);24 módulos estéticos y teóricos con ecos en Lemebel. El trabajo sobre la prostitución viril pertenece a una constelación de textos en los que Perlongher visualiza ciertos dispositivos que el capitalismo tardío estaba activando para reterritorializar flujos libidinales en su máquina productiva. Así, el modelo identitario gay fue denunciado por Perlongher como un agente del mercado que venía a reorganizar las circulaciones deseantes en la lógica del consumo; y las operaciones que el Estado, los medios de comunicación y algunas instituciones diseñaron en la emergencia y la crisis del sida, como una máquina de intervención sobre los agenciamientos corporales para redisciplinarlos. ${ }^{25}$ El pensamiento y la práctica artística de Perlongher trabajaron sobre estos temas hasta su fuga final hacia el misticismo y la experiencia extática. Desde su militancia trotskista inicial hasta la búsqueda de cocientes máximos de desterritorialización subjetiva en las experiencias del culto del Santo Daime, todos sus modos de intervención interrogaron las relaciones entre política, historia y deseo en algunos nudos de la cultura. En tal sentido, Perlongher construyó una genealogía de escrituras latinoamericanas en la que el texto de Lemebel sería un movimiento reciente. Puso en el centro de la práctica literaria las tramas entre deseo y escritura para iluminar zonas de la historia cultural latinoamericana caídas en conos de sombra. Perlongher capturó el corte provocado por la escritura de José Lezama

24 “Cantar o contar, la teoría sirve para contar. Y al antropólogo Perlongher las Mil Mesetas de DeleuzeGuattari le sirven para contar, en otro lado, el mapa de los encuentros homosexuales. Lo mismo que canta (lo que se compone o se prepara en el cuerpo barroco, en la superficie del poema y se descompone y se deshace en esa misma superficie), Perlongher lo cuenta en O Negócio do Michê con las redes nómadas, los rizomas, el deseo errante de los ghettos homosexuales paulistas, enfrentando las convenciones narrativas de las corrientes antropológicas que hacen de la identificación, la identidad y las arborescencias clasificatorias una cuestión de ordenamiento social. Fúnebre barroco, el libro concluye con la desilusión de una pérdida: el objeto contado parece disolverse en una “cirugía de la extirpación”, en una higiene de los sexos ordenados y medicalizados” (Panesi, “Detritus” 308).

25 "En la emergencia del Sida no se sabe qué es más pavoroso: si los efectos devastadores de la enfermedad en el propio plano de los cuerpos físicos, minados por una sucesión impresionante de molestias; o si otros efectos menos ‘físicos’ en el plano de la llamada moral pública, que no por ser 'discursivos', dejan de incidir en la programación contemporánea de los cuerpos, sus pasiones y sus tránsitos. [...] Las operaciones desencadenadas durante su irrupción rebasan el dolor personal de las crecientes víctimas, para extenderse al cuerpo social como un verdadero dispositivo de moralización y normalización de las uniones sensuales, derivado de las olas de pánico” (Perlongher, “El orden” 43).

Revista Iberoamericana, Vol. LXXX, Núm. 247,
ISSN 0034-9631 (Impreso) 
Lima como el momento en que el "nuevo brote barroco llega a Cuba vía España, donde García Lorca y la generación del 27 lo reivindicaban entusiasmados por los festejos del tricentenario gongorino” (Perlongher, “Caribe” 97). Persiguió en la literatura continental aquellos puntos en que "la 'lepra creadora' lezamesca mina o corroe -minoritaria mas eficazmente- los estilos oficiales del bien decir” (“Caribe” 93). Bajo la impronta de Deleuze, Perlongher definió el barroco como un estado de sensibilidad que "consistiría en cierto modo de plegado de la materia y la forma” "“Caribe” 93), y tomó de González Echevarría la idea del barroco como un arte antioccidental, "listo a aliarse, a entrar en mixturas 'bastardas' con culturas no occidentales” (“Caribe” 94). El sistema poético lezamiano fue leído por Perlongher como una máquina barroca, "un caprichoso y detallado sincretismo transcultural capaz de hilvanar las ruinas y las mutilaciones de los más variados monumentos de la literatura y de la historia, alucinándolos" (“Caribe” 94). En Lezama encontró algo "que parece constitutivo, en filigrana, de cierta intervención textual que afecta las texturas latinoamericanas: texturas porque el barroco teje, más que un texto significante, un tejido de alusiones y contracciones rizomáticas que transforman la lengua en textura” "“Caribe” 95).

Fue Severo Sarduy quien puso a circular el término "neobarroco”26 para nombrar el "encuentro entre el flujo barroco que es, a pesar de sus silencios, una constante en el español, y la explosión del surrealismo” (Perlongher, “Caribe” 98). ${ }^{27}$ A diferencia del barroco del Siglo de Oro, montado sobre el humus renacentista, el barroco contemporáneo no tiene un suelo estético uniforme; es producto "de cierto despedazamiento del realismo, paralelo al desgaste del 'realismo mágico' y de lo 'real maravilloso', la eclosión de una variedad de escrituras instrumentales más o menos transparentes” (“Caribe” 99). El neobarroco revela la "pasión por la eficacia del signo” que ya no se preocupa de remodelar "las secuencias significativas de la historia, sino de superponerles otros ciclos, invisibles para la cronología empírica o para la causalidad, pero más eficaces, más reales, incluso, que los que modelan [...] el desarrollo de las civilizaciones" (Sarduy, "Un heredero" 591, énfasis mío). Sarduy estableció con Lezama una relación de "herencia”, ${ }^{28}$ siendo la

26 "La extrema artificialización practicada en algunos textos, y sobre todo en algunos textos recientes de la literatura latinoamericana, bastaría pues para señalar en ellos la instancia de lo barroco" (Sarduy, "El barroco" 169).

${ }^{27}$ Una mirada diferente de la de Perlongher sobre la presencia del surrealismo es la de Susana Cella, para quien "la impronta surrealista en Carpentier funciona en gran medida como diferenciación de su barroco respecto del de Lezama" (155).

28 "Heredero es el que descifra, el que lee. La herencia, más que una donación, es una obligación de hermenéutica. Heredero es el que, gracias a la fulguración de un desciframiento, se apodera instantáneamente de un saber. Champollion, tan presente y no por azar, en Lezama, al traducir la piedra cifrada, al leerla, hereda en ese momento y nos transmite la noche milenaria de los jeroglíficos, el saber inscrito en el basalto; Freud, al leer las imágenes inacabadas de nuestra noche física y el acertijo de palabras que las atraviesan, descubre y hereda un espacio, un lugar, el del inconsciente" (Sarduy, "Un heredero" 596).

Sinf Revista Iberoamericana, Vol. LXXX, Núm. 247, Abril-Junio 2014, 433-468 ISSN 0034-9631 (Impreso) $\quad$ ISSN 2154-4794 (Electrónico) 
masa sucesoria el trabajo sobre la materialidad del lenguaje que denomina neobarroco. A través de esta identificación en la lectura (que procesa el texto lezamiano en la máquina teórica del grupo de la revista Tel Quel), ${ }^{29}$ Sarduy disputó la figura de Lezama a la administración cultural del Estado revolucionario cubano, haciendo audibles las aventuras sigilosas silenciadas por el canon articulado con la figura del Martí revolucionario en su centro. A su vez, Perlongher heredó a Lezama y Sarduy, y arrastró el neobarroco cubano al ámbito del Río de la Plata donde deviene "neobarroso” al hundir en el estuario la perla deforme "echada a rodar en la inmistión del lodo”. El neobarroco/neobarroso provoca agenciamientos entre materiales nobles de la alta literatura y "malas lenguas" que mezclan los "materiales más bajos y vulgares a los que se llega por un exceso de carnavalización” (Perlongher, "Nuevas escrituras” 243). Poéticas de la corporalidad, los barrocos contemporáneos albergan distintos tensores en "la relación entre la lengua y el cuerpo, entre la inscripción y la carne”, que van de la "escritura como tatuaje” de Sarduy a la "escritura como tajo" de Osvaldo Lamborghini, en medio de las cuales "se desenvuelven, grosso modo, una multiplicidad de escrituras neobarrocas” (Perlongher, “Caribe” 100). Perlonhger encaró un “casi secreto recorrido literario” por escrituras latinoamericanas filiadas por el "rechazo a cierto convencionalismo comunicacional e ‘identitario’ del lenguaje”, pero ligadas también por tratarse de experiencias marcadas por pérdidas y derrotas que se inscriben en los cuerpos textuales como "mutilaciones de los más variados monumentos de la historia y la literatura”. Lo que hay en estos textos no es tanto la representación de "la situación del perdedor" (Amar Sánchez 10), sino más bien una inscripción de la pérdida en el propio cuerpo de la escritura y en las imágenes des-hechas que por ese cuerpo circulan. Las textualidades de la genealogía que propone Perlongher llevan en su superficie (a veces como tatuaje, otras como tajo) las marcas de específicas situaciones histórico-políticas impregnadas por el autoritarismo y la violencia; pero también, de modo más general, muestran lo que falta en los relatos de los vencedores, los huecos que remiten a una pérdida fundacional operada en los cruces, tensiones, roces entre el orden de la historia y el orden del deseo. Las escrituras de Lezama, Cabrera Infante, Sarduy, Arenas, Lamborghini, Glauco Mattoso, Arturo Carrera, Echavarren, Kozer, Maquieira, Eltit (pero también Haroldo de Campos y cierto Girondo), entre otros, llevan en sus cuerpos las cicatrices de las pérdidas provocadas por los procesos de dominio, y resisten la falta con la inflación significante que "lanza el ataque estridente de sus bisuterías irisadas en el plano de la significación, apuntando al nódulo del sentido oficial de las cosas" (Perlongher, "Caribe” 96). Como "heredero" de Perlongher, Pedro Lemebel impulsa la potencia escritural neobarrosa hasta el río

29 “Si en Lezama está la tradición católica, la filosofía griega, Pascal, el Tao, entre otras cosas, en Sarduy hay un giro que los reinterpreta a la luz de las modernas teorías cosmológicas, el psicoanálisis lacaniano, la teoría literaria francesa. [...] esto supone una serie de deslizamientos que median en la filiación” (Cella 152).

\footnotetext{
Revista Iberoamericana, Vol. LXXX, Núm. 247, Abril-Junio 2014, 433-468 ISSN 0034-9631 (Impreso) ISSN 2154-4794 (Electrónico)
} 
Mapocho - "flujo de nieves enturbiadas por el chocolate amargo", "moreno, entierrado y muy indio en sus porfiadas", "arteria fecal" que "se explaya a sus anchas besando la basta deshilachada de la periferia” (Lemebel, De perlas 119-120)-, y la empapa con los residuos que se arrojan a sus márgenes, conformando el habla barrocha que deriva por los textos. Se instala así en esta línea de escrituras signadas por la pérdida, cuya dimensión ética surge no de un régimen de representación, sino de los valores que libera el trabajo con las materias significantes.

3.

Acaso estuvimos locas siempre; locas como estigmatizan a las mujeres. Pedro Lemebel

Lemebel dejó de escribir cuentos y se volvió hacia la crónica, ingresando en un género que desde la Conquista ha tenido una presencia constante en las letras latinoamericanas. Por tratarse de un tipo textual particularmente dispuesto a la hibridación y la mezcla, la crónica se acomodó a diferentes posiciones ocupadas por la escritura en la historia cultural de América Latina. El siglo XIx hispanoamericano asistió a una singular toma de conciencia de sujeto y cultura resultante de la crisis ideológica originada en la independencia de España y la llegada de las ideas de la Ilustración europea (Molloy). El pasaje de un orden abolido a otro aún no consolidado trajo para la escritura una crisis de autoridad debida al vacío interlocutorio: si ya no se escribía para la Corona ni para la Iglesia, ¿para quién o para qué, entonces? (Molloy 14). Este vacío en la alocución se hizo particularmente dramático para las escrituras que, como había sucedido en el orden anterior con textos como las cartas, crónicas y relaciones de la Conquista, la "Respuesta" de Sor Juana o las confesiones ante el Santo Oficio, por ejemplo, necesitaban de un Otro institucional que los autorizara. El vacío fue suturado por el Romanticismo que confió en la escritura como instrumento de racionalización de la barbarie (Ramos), legitimada por la enunciación del "hombre civilizado" que escribía para el grupo de los criollos aspirante a la hegemonía; fue en esta legalidad que la generación romántica escribió sus artículos políticos, de costumbres, de crítica de libros, de viajes. Ahora bien, la modernización desigual y dependiente que cambió la fisonomía latinoamericana en el pasaje del siglo xix al xx expuso los límites del proyecto romántico, y en la nueva división social del trabajo, las funciones escriturarias que antes habían ligado los letrados a la política fueron transferidas a la industria cultural en ascenso. La crónica modernista fue producto de la profesionalización del escritor, y vivió del conflicto entre materiales heterogéneos instalado en la enunciación y en la inscripción institucional del género. La crónica modernista circuló por los grandes periódicos de las capitales latinoamericanas, y configuró sus escrituras ensayando diferentes soluciones para la relación tensa entre

Revista Iberoamericana, Vol. LXXX, Núm. 247, Abril-Junio 2014, $433-468$
ISSN 0034-9631 (Impreso) 
literatura y periodismo (Ramos). Entre otras mixturas, Francisco Morán señala que hubo "ciertos intercambios de flujos textuales que definitivamente conectan al amarillismo y al modernismo" (143). El sensacionalismo impregnó una zona de la escritura modernista (la más cercana al decadentismo, tal vez habría que agregar) y también la prensa amarillista de fines del siglo xix; modernismo y amarillismo compartieron la misma fascinación por lo caído fuera de la ley, "objetos, sucesos e individuos en los que se percibe una transgresión de algún tipo, una violación de la Ley” (146). Dado que el sensacionalismo es un fenómeno de masas, "la escritura, al pasar a la cultura de masas, pierde o ve menoscabado su sentido racionalizador o civilizador" (151) en el que los letrados románticos habían confiado. Julián del Casal fue uno de los modernistas próximos a la prensa amarilla, por su trabajo como cronista de sucesos en periódicos como La Caricatura y La Discusión. En estas crónicas casalianas, de diferente tenor que los trabajos que publicaba en La Habana Elegante, aparece un sujeto perverso, el "paseante de los antros habaneros" que "no consigue distinguir diáfanamente al criminal del ciudadano corriente, no a la escritura del crimen” (Páginas 190, énfasis mío) ${ }^{30} \mathrm{La}$ medianía de la realidad circundante lleva hacia los márgenes la mirada de este sujeto desencantado e inconforme, pero su enunciación sigue situada en "las frivolidades de los salones elegantes (Augier, XXXVII). Para las escrituras del xix el sensacionalismo fue un shifter que las puso en contacto con lo abyecto, la membrana a través de la cual el ojo modernista miró el margen como lo no integrado al nuevo orden. Lo caído fuera de la ley también es material de las crónicas de Lemebel y las pone en contacto con textos como los de Casal. Pero en la escritura de Lemebel el sensacionalismo se ha retirado porque en su emergencia no fueron pensados como textos para la industria cultural; además, la enunciación de las crónicas lemebelianas no requirió de ningún operador de empalme con un "otro": el habla "barrocha" acontece en los márgenes como lo no integrable. Desde el "Manifiesto", la enunciación de Lemebel descarga sobre las pérdidas presentes y pasadas la energía política que sostiene la resistencia de la escritura a su asimilación, manteniendo una relación tensa con los procesos integradores de las modernizaciones. El ojo coliza de la crónica lemebeliana no mira hacia los márgenes, mira en y desde los

30 “Cansado de recorrer la población, buscando algo nuevo que admirar; de sentir la nostalgia de un museo en el que los espíritus contemplativos pueden tomar largos baños de antigüedad; [...] y de presenciar el contagioso e incesante descontento de la humanidad [...]; resolví marcharme ayer a uno de los sitios más repugnantes de la capital, al Matadero. [...] Atravesando un callejón anchuroso, quemado por los rayos de un sol de fuego, con los pies hundidos en la blanda alfombra de polvo, pude contemplar varias cosas. A la derecha, una cuadrilla de presidiarios, con la pica en movimiento y el grillete a lo largo de la pierna [...]. A la izquierda, bajo portales mugrientos, agujereados y apestosos, varios hombres robustos, cuchillo en mano y ensangrentadas las ropas, abrían, vaciaban y sumergían miembros de animales [...]. Un poco más lejos a la orilla del río, se alineaban las barracas habitadas por las gentes del lugar, semejantes a islotes negruzcos en que han venido a refugiarse los supervivientes del naufragio social" "El matadero" 320-321, énfasis míos).

Revista Iberoamericana, Vol. LXXX, Núm. 247,
ISSN 0034-9631 (Impreso) 
márgenes; y a los discursos integradores opone el valor de su diferencia, reinstalando una idea de la política como antagonismo contra las políticas del acuerdo.

La escritura de Lemebel produjo un pliegue en la tradición de la crónica, porque instaló su enunciación en y como lo otro de la modernización. Si de diferentes maneras la crónica del siglo xix identificaba y denunciaba exclusiones en los procesos modernizadores (y algunos textos de José Martí son paradigmáticos en este sentido), la enunciación de Lemebel pliega el género al hacerlo nombrar como propios los espacios de lo diferente, las rugosidades que alojan lo excluido. La crónica modernista operó de modo análogo al que Marshall Berman identificó en Marx, Nietzsche y Freud: una crítica de la modernidad, en los términos que la misma modernidad había producido. ${ }^{31}$ En el Chile de la década de 1990, la escritura de Lemebel extendió las experiencias del género al repeler los significados estables y los soportes discursivos configurados por la modernidad neoliberal, nombrando lo que falta en los relatos oficiales y mediáticos con los tonos de la lengua materna y mapuche.

“Anacondas en el parque” abre La esquina es mi corazón (1995), primer libro de crónicas de Pedro Lemebel. En su incipit el texto presenta una cláusula adverbial independizada (procedimiento recurrente en esta escritura), que condensa uno de los temas fuertes de esta producción: las paradojas de la modernización neoliberal frente a los modos multiformes del deseo..$^{32} \mathrm{El}$ "relámpago modernista" cae agresivo y alienante sobre el espacio público, "simulando un Versalles criollo como escenario del ocio democrático", "donde la maleza se somete a la peluquería bonsáy del corte milico" (9). Entre los dispositivos de control, el ojo coliza captura escenas donde la potencia del deseo repone aquello que los relatos de la urbanidad han obturado. Ojo de loca no se equivoca ${ }^{33}$ y hace zoom sobre los cuerpos en devenir animal ${ }^{34}$ que se agencian

31 "Cuando se ven a tantos hermosos países amenazados, como lo están siempre, por naciones avaras, roídos por sus odios domésticos, buscando, con esfuerzos desesperados, un modo de satisfacer su amor al lujo, entre sus indígenas que temen a los blancos, sus aristócratas que aborrecen a los negros, sus aldeanos que no trabajan por miedo a ver sus campos arrasados por las revoluciones, sus hombres brillantes envilecidos por la necesidad de vender a los afortunados triunfadores su talento y su honor -cuando se ve, a pesar de todo, crecer a esos pueblos, y aspirar a la vida, y pedir en su hermoso idioma español, con su fogosa e inagotable elocuencia, su puesto en el concierto de los grandes pueblos-" (Martí 227, énfasis mío).

32 "A pesar del relámpago modernista que rasga la intimidad de los parques con su halógeno delator, que convierte la clorofila del pasto en oleaje de plush rasurado por el afeite municipal” (9).

33 “Ojo de loca no se equivoca” es el título de la columna que Lemebel escribía en el diario santiaguino $\mathrm{La}$ Nación durante 2005.

34 "Un lanzarlo a recorrer el maicillo como áspid en celo"; "en plena humedad, le enciende la selva rizada del pubis, chupándole con lengua de lagarto sus cojones de menta"; "estrangulando la víctima en el muñeco vudú que derrama su ponzoña de crótalo entre los dedos"; "serpentean los senderos como anacondas perdidas, como serpientes de cabezas rojas que se reconocen por el semáforo urgido de sus rubíes" (11-12, énfasis míos).

Revista Iberoamericana, Vol. LXXX, Núm. 247, Abril-Junio 2014,
ISSN 0034-9631 (Impreso) 
sustrayéndose a la "paranoia del espacio público". Por el trazado de los recorridos y usos reglamentados "se acercan parejas de la mano que pasan anudando azahares por la senda iluminada de la legalidad", fingiendo "no ver el amancebamiento de culebras que se frotan en el pasto”, comentando "en voz baja 'eran dos hombres ¿te fijaste?”” (10). Pero las "futuras nupcias” también se desmarcan de lo reglamentario al "hacer el amor en la dulzura del parque, porque no tuvieron plata para el motel, pero gozaron como nunca en esa intemperie verde, con ese espectador que no pudo aplaudir porque tenía las manos ocupadas” (10). El relato expone pliegues en la separación entre lo público y lo privado que organiza la mentalidad burguesa, y revela al deseo como una materia proteica e insumisa. El texto propone que entre las esferas de lo público y lo privado no hay un límite, sino un pliegue ${ }^{35}$ y allí se instala la mirada y la enunciación de la crónica lemebeliana: "Obreros, empleados, escolares o seminaristas [...] abandonan la piel seca de los uniformes, para tribalizar el deseo en un devenir opaco de cascabeles” (12). Los flujos libidinales se pliegan y repliegan sobre el campo de lo público, infliltrándolo con los excedentes que habían sido confinados a la esfera de lo íntimo o a los márgenes de lo abyecto. La escritura de Lemebel se monta sobre los movimientos del pliegue y, parafraseando a Nelly Richard, convierte el residuo (social) en excedente (estético, crítico) que desarticula la lógica de la mercancía que desecha lo que sobra. Otra crónica del mismo libro, "Baba de caracol en terciopelo negro", postula el cine como un lugar de expansión de deseos homoeróticos, un punto de intensidad en el tejido urbano marcado por la convergencia de flujos deseantes que se dejan "libar en el anonimato de la cámara oscura, como retorno a la seguridad del vientre” (29). En la oscuridad de la sala, hay cuerpos actuando una función que resignifica la coreografía de artes marciales que Bruce Lee desarrolla en la pantalla, "tiñendo el cinturón negro de rosa y de primer dan a tercer sexo” (28). El texto (con)funde los dos espectáculos, impregnando

${ }^{35}$ Gilles Deleuze entiende el pliegue en dos sentidos: espacial y operatorio, y apela a esta noción para pensar la imaginación barroca del espacio y sus procesos (inseparables) de conceptualización. El pliegue es lo que separa y da cuenta de la heterogeneidad (la fundamental, cuerpo y alma, y de otras que se asocian a ella como afuera y adentro, superficie y fondo, etc.); y trabaja sobre una diferencia que no cesa de desplegarse y replegarse a cada uno de los lados. Pero también relaciona, porque señala una escisión donde cada término reenvía al otro. Se establece el juego de tensión entre dos términos, uno de los cuales es siempre la misma cosa, y en el otro todo difiere. "El Barroco no remite a una esencia, sino más bien a una función operatoria, a un rasgo. No cesa de hacer pliegues. No inventa la cosa: ya había todos los pliegues procedentes de Oriente, los pliegues griegos, romanos, románicos, góticos, clásicos... Pero él curva y recurva los pliegues, los lleva hasta el infinito, pliegue sobre pliegue, pliegue según pliegue. El rasgo del Barroco es el pliegue que va hasta el infinito. [...] diferencia los pliegues según dos direcciones, según dos infinitos, como si el infinito tuviera dos pisos [...]. Se dice que un laberinto es múltiple, etimológicamente, porque tiene muchos pliegues. Lo múltiple no es sólo lo que tiene muchas partes, sino lo que está plegado de muchas maneras" (El pliegue 11). "Lo propiamente barroco es esa distinción y distribución en dos pisos. [...] el mundo con dos pisos solamente, separados por el pliegue que actúa de los dos lados según un régimen diferente, es la aportación barroca por excelencia” (44).

Revista Iberoamericana, Vol. LXXX, Núm. 247,
ISSN 0034-9631 (Impreso) 
de deseo las acrobacias karatekas del film que seducen "al chino mapuche de la pobla, que todos los días miércoles se erecta chamuscado en el cinema Nagasaki”, “donde se cruzan la periferia desechable del nuevo orden, con el sexo místico y desconocido de los orientales” (28, énfasis mío). El cine deviene zona de pliegue, "un territorio pendular, que oscila según los intermedios del programa” (29), y es invadido por el despliegue y repliegue libidinal que mezcla los residuos de la modernidad con "otros más burgueses” que "serpentean en la sala como nube de carne que exhala vapor ácido y aromas sintéticos” (29).

La escritura de Lemebel se satura de imágenes de pliegue (de lo público y lo privado, de clases populares y burguesas, de distintas performances genéricas, de diversos regímenes de la pulsión), porque el pliegue dice una verdad del deseo homosexual. Las sexualidades disidentes (y hay aquí una clave de su historicidad) se han configurado bajo el estigma de la injuria, ${ }^{36}$ que con la violencia de su fuerza ilocutoria revela el modo de estar en el mundo a quien no desea sobre el canon de la ley heteronormativa. La injuria como acto de habla produce un corte en lo real (de los cuerpos) que deja la cicatriz, la marca, la huella de lo amputado que ha caído en el silencio. El pliegue dice la verdad de una pérdida primera operada por un doble movimiento: la naturalización de la ley heteronormativa (que como lenguaje, como “conciencia práctica”, es un medio de la producción material de cuerpos, géneros, deseos y sus “mitologías”); 37 y la correlativa invisibilización de los restos que la ley dejó fuera de su jurisdicción. En consecuencia, el deseo homoerótico sólo ha podido transitar por circuitos signados por lo clandestino, lo furtivo, lo anónimo, y hasta lo peligroso, configurándose como poblador errante de los márgenes y moldeando su goce en los movimientos de esos espacios. Es un deseo malandra, arrabalero, roto. Ésta es la verdad de unos deseos y sus goces desechados y confinados a las orillas de lo abyecto, que Lemebel escribe como una verdad política al reivindicar las sexualidades arcaicas o populares (Perlongher) como formaciones históricoculturales resistentes a los patrones normalizadores del deseo (la ley heteronormativa, pero también la identidad gay que le pide a la ley un lugar en su espacio de tolerancia),

36 “'Sucio marica’ (o ‘sucia tortillera') no son simples palabras emitidas casualmente. Son agresiones verbales que dejan huella en la conciencia. Son traumatismos más o menos violentos que se experimentan en el instante pero que se inscriben en la memoria y en el cuerpo (porque la timidez, el malestar, la vergüenza son actitudes corporales producidas por la hostilidad del mundo exterior). Y una de las consecuencias de la injuria es moldear las relaciones con los demás y con el mundo. Y, por tanto, perfilar la personalidad, la subjetividad, el ser mismo del individuo" (Eribon 29).

${ }^{37}$ En Mitologías, Roland Barthes planteaba el mito como una determinación social, como un reflejo pero que aparece invertido: "el mito consiste en hacer de la cultura naturaleza, o al menos en convertir en 'natural' lo social, lo cultural, lo ideológico, lo histórico: lo que no es sino un producto de la división de clases y sus secuelas morales, culturales, estéticas, se presenta (se enuncia) como algo que 'cae por su propio peso'; los fundamentos totalmente contingentes del enunciado, bajo el efecto de la inversión mítica, se convierten en el sentido común, la Norma, la Opinión común, en una palabra, la Endoxa (figura laica del Origen)” (“La mitología” 83).

Revista Iberoamericana, Vol. LXXX, Núm. 247, Abril-Junio 2014, $433-468$
ISSN 0034-9631 (Impreso) 
y sus modos de producción solidarios. Lemebel escribe la verdad política inscripta en los residuos errantes de los márgenes, y desactiva entonces el eufemismo utilizado por Oscar Wilde y nombra el deseo que "no osa decir su nombre”. Hay en las crónicas una poética que toma los procedimientos de nominación del “mundo coliza”, donde el nombre es el soporte de imágenes, una figura que desnaturaliza los mecanismos genéricos exhibiendo performances que, por medio de la hipérbole, desplazan y desestabilizan las fijaciones identitarias. Mirando a través del “cristal obsceno de sus carcajadas”, la loca nombra “desordenando el supuesto de los géneros” (26), “inventando chapas y sobrenombres que relatan pequeñas crueldades, caricaturas zoomorfas y chistosas ocurrencias” (62, énfasis mío). En el habla barrocha el nombre es más extenso que en las lenguas mayores, y no se agota en las categorías gramaticales que tradicionalmente cumplen su función. Si todas las categorías establecen identidades, entonces cualquier ítem lexical puede ser capturado por esta máquina de fugas identitarias para minorizar “esa marca indeleble del padre” que es el nombre civil, y diseminar una "colección de apodos que ocultan el rostro bautismal” (62). El habla barrocha saca la lengua de sus carriles habituales volviéndola informe, inacabada, en un delirio significante que hace bascular la integridad del lenguaje. ${ }^{38}$ Contra toda acción identitaria e identificatoria, el nombre coliza excede, desfigura, “desborda los rasgos anotados en el registro civil”, y desbarata la pretensión ontológica de los géneros al negarse a las operaciones sociales que determinan su "ser". El habla barrocha pertenece al "clan sodomita siempre dispuesto a reprogramar la fiesta, a especular con la semiótica del nombre hasta el cansancio”, 39 para simular "un parecer que incluye momentáneamente a muchos, a cientos que pasan alguna vez por el mismo apodo” (63, énfasis mío). Así, el nombre se aparta de su estado metafórico (esto es, representativo), para volverse una imagen que no está en lugar de ninguna otra cosa que no sea ella misma, y se relaciona por contigüidad. Idelber Avelar

${ }^{38}$ Gilles Deleuze ha señalado que en literatura no se trata de imponer una forma a una materia vivida, sino más bien de decantar hacia lo informe, o lo inacabado. Escribir, afirma Deleuze, es siempre un asunto de devenir, siempre inacabado, siempre en curso, puro proceso que desborda cualquier materia vivible o vivida: se deviene-mujer, se deviene-animal, se deviene molécula. No se deviene Hombre: el hombre se presenta como una forma de expresión dominante que pretende imponerse a cualquier materia, mientras que mujer, animal, molécula contienen siempre componentes de fuga que se escamotean a la propia formalización Los grandes escritores (Deleuze piensa en Kafka, Proust, Melville, Beckett) presentan la escritura como una enunciación colectiva de un pueblo menor, o de todos los pueblos menores, que sólo encuentra su expresión en y a través del escritor. Así, el objeto último de la literatura es poner de manifiesto en el delirio la creación de una salud, la invención de un pueblo: una posibilidad de vida (Crítica y clínica).

39 "La especulación es también un género literario. La ficción especulativa [...] inventa un universo diferente del conocido y lo funda desde cero. También propone otro modo de conocimiento. No pretende ser verdadera ni falsa [...]. La especulación es utópica y despropiadora porque no sólo concibe otro mundo y otro modo de conocimiento, sino que lo postula sin dinero y sin propiedad [...]. Por eso toma ideas de toda parte y se apropia de lo que le sirve” (Ludmer 10, énfasis mío).

Revista Iberoamericana, Vol. LXXX, Núm. 247,
ISSN 0034-9631 (Impreso) 
advierte que la relación del mercado con la historia se pretende metafórica, en tanto tiende a sustituir, a reemplazar, a incorporar el pasado como una totalidad plena, sin residuos; se rechaza entonces la metonimia por su carácter inacabado, repugnante a la ratio de lo nuevo. Esta situación se habría extremado en el capitalismo tardío, continúa Avelar, asentado en la infinita sustitutibilidad donde todo puede ser reemplazado, haciendo de cada objeto y de cada información un cuerpo metaforizable por cualquier otro. Lemebel instala en sus textos una tropológica diferente de la sancionada por el mercado, pero distinta también de las narrativas del Cono Sur que en los años ochenta y noventa privilegiaron la alegoría para sus figuraciones. A la voluntad metafórica de la cultura de mercado, las crónicas de Lemebel oponen una textualidad "sintagmática", iterativa y no acabada, que yuxtapone imágenes ("nombres”) que cargan con "detalles y anomalías" (residuos) componiendo una cadena fracturada y resistente a la totalización simbolizante. Comparte con las figuraciones alegóricas su interpelación de la historia desde las pérdidas legibles en la materialidad de los cuerpos y los objetos, pero se aleja en el modo de tramitar las faltas. El planteo de Avelar retoma el vínculo benjaminiano entre alegoría y duelo, y lo asocia a la noción de "cripta” para pensar la alegorización en las narrativas de las dictaduras y las posdictaduras. En su argumento, la cripta aloja el objeto perdido como manifestación de la persistencia fantasmática de un duelo irresuelto, y así la alegoría como cripta retiene las totalidades quebradas que evoca, deviniendo síntoma melancólico de un duelo obturado. En la escritura de Pedro Lemebel no hay síntoma asociado a la simbolización, porque la estructura de su texto no es neurótica: su régimen es la perversión. Se trata de una escritura que trabaja en el limo de lo abyecto -aquello que ha sido evacuado del cuerpo (social), la suciedad "que se desecha del sistema simbólico" (Kristeva, Poderes 63)-, ${ }^{40}$ pero donde lo abyecto no es lo otro que ha sido expulsado sino la propia materia (corporal, discursiva, histórica). La escritura de Lemebel es perversa en tanto nombra como propio el légamo de residuos que el socius expulsa, desconociendo los límites que el orden simbólico (la metáfora paterna) impone al cuerpo (social). Una vez más la escritura vuelve pliegue lo que la ley instauró como límite.

El nombre "coliza" es un esperpento que "ridiculiza embelleciendo la falla, la hace propia, única” (64, énfasis mío). A diferencia de la alegoría que trabaja con ruinas, el esperpento lemebeliano toma residuos como sus materiales, y esta divergencia marca posiciones y miradas diversas sobre la derrota. Mientras las alegorías "retratan un cierto intervalo, un período circunscripto en que la historia se suspende, y el tiempo secular, progresivo, da lugar a experiencias que parecen eternalizadas" (Avelar 57), el esperpento de Lemebel es una imagen que, regida por la iteración, no cesa de producirse incorporando

40 “[...] el rechazo de los cuerpos por su sexo, sexualidad o color, es una 'expulsión' de la que se desprende una ‘repulsión’ que establece y refuerza identidades culturalmente hegemónicas” (Butler, El género 262).

\footnotetext{
Revista Iberoamericana, Vol. LXXX, Núm. 247, Abril-Junio 2014, 433-468 ISSN 0034-9631 (Impreso) ISSN 2154-4794 (Electrónico)
} 
materiales marcados por historicidades diversas como huellas de las pérdidas silenciadas en la historia, actualizadas en el presente. De esta forma, en el esperpento la historia no está suspendida, sino marcada por una temporalidad de aspecto imperfectivo, un presente continuo que dice lo permanente e inacabado de las acciones de domino y exclusión. El esperpento lemebeliano es una imagen que nombra significando en la pérdida y con ella. Si, como quiere Avelar, la alegoría es una imagen arrancada del pasado que remite a totalidades que han sido quebradas, el esperpento de Lemebel se diferencia porque aparece "escurriéndose de la postal sepia de la familia” y se sacude "las plumas del derrumbe ideológico que jamás nos contuvo” (Loco 124). El esperpento repele la melancolía que impregna la figuración alegórica porque pertenece a una historia de lo menor que no reconoce ninguna totalidad pretérita como propia: no hay un mundo abandonado por los dioses, porque nunca hubo dioses sosteniendo el mundo.

El esperpento, es sabido, como género literario surgió en 1920 con Luces de Bohemia de Ramón del Valle-Inclán quien tomó el término del habla popular, donde designaba lo feo y lo ridículo. Valle-Inclán bautizó como esperpento lo que consideró un género nuevo, pero cuyos antecedentes la crítica ha rastreado en Quevedo, la corriente expresionista que recorrió Europa del siglo xix al xx y la pintura de Goya, especialmente su serie de grabados Los desastres de la guerra. En la escena XII de Luces de Bohemia el protagonista define el esperpento: "Los héroes clásicos reflejados en los espejos cóncavos dan el esperpento” (Valle-Inclán 932). Desde la óptica de Valle-Inclán, la tragedia era un género demasiado noble para representar la realidad española de su época ("España es una deformación grotesca de la civilización europea” Valle-Inclán 939). Valle-Inclán planteó sus esperpentos en controversia con las reglas de la preceptiva clásica, manteniendo sólo la unidad de tiempo y colocando la perspectiva, el punto de vista (la "mirada desde”) en el centro de su sistema de representación. Contra la mirada “desde abajo” de las preceptivas clásicas o la “mirada desde el mismo plano” en el teatro isabelino, Valle-Inclán planteó una “mirada desde arriba”, y especificó el esperpento como un "otro” mirado desde un lugar de superioridad. En la propuesta de Valle-Inclán, la mirada “desde arriba” provoca una sistemática deformación de la realidad (el reflejo en un espejo cóncavo), explotando ciertos rasgos que se vuelven grotescos y absurdos. Hay, además, un uso de la diversidad lingüística que compone una lengua desgarrada por la mezcla donde ingresan, junto al habla popular, sociolectos bajos y jergas, pero también cultismos, gitanismos, arcaísmos, voces de otras lenguas, el habla pretenciosa de la alta burguesía. El estilo de Valle-Inclán combina en sus metáforas elementos de campos semánticos opuestos, y también hace uso de la sinécdoque para describir personajes con rasgos que ridiculizan a través de lo grotesco o lo macabro.

Muchos de los elementos carnavalizantes y diglósicos presentes en Valle-Inclán están en Lemebel. Pero en la escritura del chileno, el modo de ver no funda un género sino una modalidad de la imagen. El esperpento lemebeliano no presenta una "mirada

\footnotetext{
Revista Iberoamericana, Vol. LXXX, Núm. 247, Abril-Junio 2014, 433-468 ISSN 0034-9631 (Impreso) ISSN 2154-4794 (Electrónico)
} 
desde arriba” como la de Valle-Inclán, sino una mirada horizontal, desde el mismo plano, que se acerca persiguiendo el detalle, no como garantía de verdad a la manera realista-romántica, sino como huella de las faltas, como la marca de las derrotas. Los procedimientos del nombre (imagen) en el mundo "maricueca" definen el principio constructivo del esperpento, fundado en el efecto de zoom de la mirada del ojo coliza que focaliza sobre el detalle, hiperbolizando, desajustando toda proporción: “esa negrura que se grita y llama y se nombra incansable, ese apodo que al comienzo duele, pero después hace reír hasta a la afectada" haciendo "de la caricatura una relación de afecto" (64, énfasis mío). ${ }^{41}$

4.

...las huellas de ese carnaval ceniciento...

Pedro Lemebel

"La esquina es mi corazón (o los New Kids del bloque)" es la crónica de la que el primer libro de Lemebel toma su nombre. La cláusula parentética del título es una figura que presenta de modo despojado el mecanismo matriz de esta poética. El nombre de una exitosa banda comercial de los años noventa (una formación de adolescentes con melodías fáciles y ritmos pegadizos) que funcionó como marca de moda vendida a través de un relato sobre la juventud, aparece intervenido por el sintagma "del bloque". El "bloque" es lo desechado por el relato sobre la juventud latinoamericana propuesto por el mercado desde las cadenas televisivas como la MTV. Los "bloques” son los complejos de viviendas populares que albergan parte de la "pobla" santiaguina, construidos en las orillas de la capital chilena y "soporte precario de intimidad, donde los resuellos conyugales y las flatulencias del cuerpo se permean de lo privado a lo público" (12). Perdedores de su presente, “carne de cañón en el tráfico de las grandes políticas” (20), los nuevos chicos del bloque son los adolescentes de la transición y la posdictadura ${ }^{42}$

41 “Los mil nombres de María Camaleón”, texto de Loco afán, finaliza con una lista de 106 nombres "rescatados de las densas aguas de la cultura mariposa" (65); algunos de ellos son: La Cuando No, La Siempre en Domingo, La María Silicona, La Maricombo, La Faraona, La Carmen Miranda, La Loca de la Cartera, La Loca del Moño, La Tacones Lejanos, La Saca Corchos, La Chupadora Oficial, La Licuadora, La Multiuso, La Pituca, La Putifrunci, La Claudia Escándalo, La Yo No, La Pide Fiado, La Poto Ronco, La Abeja Maya, La Ahí Va, La Ahí Viene, La Fácil de Amar, La Si Me Llaman Voy, La Poto Asesino, La María Misterio, La María Sombra, La María Acetaté, La María Sarcoma, La Frun-Sida, La Bien Pagá, La Zoila Kaposi, La Sui-Sida, La Depre-Sida.

42 "El cierre de los canales de participación social -al que conviene agregar la exclusión económica- ha conducido a una gran parte de los jóvenes a identificarse [...] como los defensores guerreros del grupo opuesto al Estado; otros jóvenes, entretanto, han escogido las estrategias de participación ilegal a través de la delincuencia organizada. En este último caso, el actor se manifiesta con un instrumentalismo discreto, mientras que los “guerreros” escogen, al contrario, la expresión espectacular” (Dubet 97).

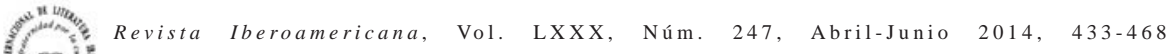
ISSN 0034-9631 (Impreso) ISSN 2154-4794 (Electrónico) 
que, “expuestos y dispuestos a las acrobacias de su trapecio proletario” (15), actúan la misma violencia que los somete ${ }^{43}$ para las cámaras de los noticieros y su show de la juventud criminalizada. Vidas al borde “de estos benjamines poblacionales [que] se van almacenando semana a semana en los nichos del cementerio”, y repiten “más allá de la muerte la estantería cementaria del hábitat de la pobreza” (19). Todos estos significados se expanden al intervenir la lengua del mercado (New Kids on the Block) incrustándole en su materia sus propios residuos. Así reinscripto, el sintagma “el bloque” configura una metonimia (de los sujetos que lo habitan y sus modos de estar en el mundo) que, por las intensidades que instala, se vuelve una imagen que no está en lugar de ninguna cosa diferente de ella misma. Los new kids de la "pobla” son los des-hechos descartados por “el futuro despegue capitalista en la economía de esta 'demosgracia'”, "hacinados en el lumperío crepuscular del modernismo” (20). Los “pendex” son los nuevos perdedores, y su pérdida transcurre en la experiencia de un presente vivido en condiciones de existencia que impiden construir valores colectivos que les permitan reconocerse en un pasado o imaginar un futuro; la pérdida de los nuevos chicos del bloque no tiene salida hacia un sentido ético de resistencia, no hay posibilidad para la significación política de la experiencia: son los desterrados de la polis para quienes "el mañana es un cuento demasiado literario que [...] sumerge en un bostezo aburrido” (88).

El cuerpo de los “pendex”, performado en "el desquicio de la vida, de por sí violenta, de los marginados en la repartición del espacio urbano” (19), es un mapa de los márgenes del Mapocho, no como copia sino como efecto de superficie, como "el registro de su funcionamiento en tanto práctica de su propio movimiento” (Perlongher, “Los devenires” 66). Errantes por el hacinamiento y la promiscuidad, su propio régimen performativo inscribe sobre estos cuerpos (a veces como tatuaje, otras como tajo) los movimientos de los márgenes y sus relaciones tensas con el afuera. Actúan ser la ley de su territorio montando escenas de dominio, hasta que llegan "los civiles y empiezan las carreras y los lumazos” (Lemebel, La esquina 19); se agencian a los cuerpos de las locas en "el bambolear homosexuado que en el flirteo del amor erecto amapola su vicio” (87); están expuestos “al crimen, como desecho sudamericano”, "para violar, robar, colgar si ya no se tiene nada que perder y cualquier día los encontrarán con el costillar al aire” (20). Sobre el cuerpo de los chicos del bloque el ojo coliza se desliza reconociendo las intensidades de los movimientos del margen. La imagen del cuerpo

43 “[...] la yerba alivia la pena y el peso del barro en los zapatos. Más bien en las zapatillas Adidas que le pelamos a un loquillo pulento que vino a mover. Era broca y se quedó tieso cuando le pusimos la punta y le dijimos ‘coopera con las zapatillas loco', y después con los bluyines y la camisa Y de puro buenos no le pusimos el ñato, porque estaba tiritando. Y aunque era paltón nos dio lástima y le contamos hasta diez, igual como nos contaban los pacos, igual se la hicimos al loco, porque aquí la ley somos nosotros, es nuestro territorio, aunque las viejas reclaman y mojan la escala para que no nos sentemos” (La esquina 18, énfasis mío).

Revista Iberoamericana, Vol. LXXX, Núm. 247,
ISSN 0034-9631 (Impreso) 
de los "pendex" es el mercado persa, contracara que invierte "el súper mall de crédito privado por un negativo de remate público" (Loco 105). Como las subjetividades desechadas del consumo neoliberal que convoca, "el mercado popular traza su propia historia en la mezcla de retazos paleolíticos con la producción en serie de mercancías taiwanesas” (106, énfasis mío). A diferencia del presente clausurado e hiperbólico que satura la temporalidad de la sociedad de consumo, con sus imágenes globales (metáforas y símbolos) que representan un núcleo de valores ligado de modo circular a lo nuevo y la moda, en el mercado persa cohabitan las diferentes temporalidades inscriptas en las materias desechadas por el otro mercado, y la metonimia es la figura clave en su retórica de yuxtaposición de restos. Del mismo modo, las materias residuales de las subjetividades des-hechas están marcadas por distintas historicidades, cuya contigüidad expande una temporalidad compleja con efectos de anacronismo que traducen los conflictos. Como los "pendex" de la "pobla", "colecciones de músculos desnutridos", "con su cuerada mapuche, su pellejo morocho" (67) que bailan "súper música de los New Kids para desmayarte muy adentro, fumarse todo y a lo que venga" (17). Como la Madonna del Barrio San Camilo, "con su cara mapuche mostrando las tetas a los clientes mientras dice 'Mister, lovmi plis'” (Loco 38).

A diferencia del cuerpo del "péndex", el de la "loca" no es un mapa sino un pliegue entre el margen y el no-margen, un envaginamiento, una mucosa. El cuerpo de la loca es el esfínter del margen, el pliegue que aloja el goce perverso donde coinciden erotismo y excreción, el "ano piadoso" "retumbando panderetas y timbales en el ardor de la colitis sidosa” (20). La loca es un pliegue cuyos movimientos desnaturalizan las ontologías genéricas, mostrándose como un residuo de la ficción social que organiza la estilización de los cuerpos como masculinos o femeninos por medio de prácticas repetitivas, que producen efectos de sentido sobre un conjunto de rasgos que de otro modo permanecerían discontinuos (Butler). ${ }^{44} \mathrm{El}$ cuerpo de la loca es ininteligible para

${ }^{44}$ Judith Butler considera el sistema sexo-género como una construcción ideal que regula y administra las prácticas que el mismo sistema ha generado. Lo masculino y lo femenino se configuran performativamente, mediante prácticas repetitivas que producen efectos de sentido. Butler retoma la lectura que Derrida hizo de la teoría de los actos de habla de Austin, y señala que la potencialidad del preformativo radica en su necesidad de la repetición y la cita. Para Butler el proceso de sexualización y atribución genérica de un cuerpo es un fenómeno ritualizado y repetitivo, "un performativo institucionalizado que crea y legisla la realidad social al requerir la construcción discursiva/perceptual de los cuerpos de acuerdo con los principios de diferencia sexual” (El género 17). El género estiliza (construye) el cuerpo por la repetición de enunciados, movimientos, gestos, que lo van moldeando como integrado al orden de lo masculino y lo femenino. El sexo es una norma que, basada en el imperativo heterosexual, otorga sentido a los cuerpos; el género también es una norma, cuyo deber ser reinscribe en el cuerpo requiriéndole una identidad no ambigua (masculina o femenina) que permita llevar una "vida inteligible": sólo tienen un sentido estable los cuerpos adaptados a la norma. Butler acude a la idea de "interpelación” de Althusser para demostrar cómo se imprime un sexo a los cuerpos, y cómo se definen las reglas de inteligibilidad corporal basadas

Revista Iberoamericana, Vol. LXXX, Núm. 247, Abril-Junio 2014, $433-468$
ISSN 0034-9631 (Impreso) 
el régimen de lectura de la heteronormatividad, y en tal sentido es una sinécdoque de los márgenes de lo social. Como todo margen, es un espacio de permeabilidad (de pliegue), y por lo tanto de contaminación y peligro para un sistema donde lo interno y lo externo "sólo tienen sentido con referencia a un límite mediador que combate por la estabilidad” (Butler, El género 262-263). Las locas de los márgenes del Mapocho son restos de "los años de la dictadura que educaron virilmente los gestos" (Loco 26); sus cuerpos deseantes llevan materias de un pasado hecho de otros pliegues y anterior a "la desfunción de la loca carcomida por el sida, pero principalmente diezmada por el modelo importado del estatus gay” (26). En el mercado persa, el cuerpo de la loca es el pliegue entre el interior y el exterior, la membrana por donde se penetra y se evacúa, el esfínter perverso que confunde los binarismos que significan su orificio "en el disparate coliza de ir quebrando mundos como huevos” (87). Pero también el cuerpo de la loca es la superficie donde el sida continúa la masacre de la dictadura, en la cadena de la barbarie dominadora.

La escritura de Lemebel esperpentiza el cuerpo de "la loca sidada”, y así sustrae la enfermedad y sus metáforas de los módulos genéricos y retóricos con que los discursos médicos y mediáticos han construido un sentido común. Las crónicas de Lemebel montan el sida sobre una ópera barrocha y travesti que, en plena crisis de la peste, cambia las jeringas por las plumas para articular una lengua insumisa a la "neocolonización" instaurada a partir de la plaga. En su crisis, el sida fue una enfermedad considerada intratable y caprichosa, cuando ya la medicina aseguraba la potencial cura de toda enfermedad. Como lo habían sido la tuberculosis y el cáncer, el sida fue una enfermedad considerada "misteriosa” y su circulación (por los cuerpos, los discursos, las prácticas de los sujetos) "tiene inevitablemente algo de infracción; o peor, algo de violación de un tabú” (Sontag, La enfermedad 14). Estas enfermedades “misteriosas” son un campo fértil para la imaginación metafórica, y sobre ellas se arman relatos, que muchas veces dicen más de conflictos presentes en los cuerpos sociales que de los procesos que atraviesan los cuerpos afectados. Susan Sontag distinguió dos cadenas metafóricas en los relatos sobre el sida: por un lado, el microproceso del sida se ha descripto como una invasión, rasgo que compartiría con el cáncer; por otro, para su transmisión "se invoca

en un orden de género y heterosexualidad. La consecuencia es que los cuerpos que no presentan una continuidad entre sexo y género son impugnados por su inteligibilidad. El sistema sexo-género necesita producir sus fronteras, y para ello produce y rechaza un exterior abyecto que excede la matriz de género que delimita un espacio concreto definido como "lo humano": "La marca de género aparece para que los cuerpos puedan considerarse cuerpos humanos; el momento en que un bebé se humaniza es cuando se responde a la pregunta ‘¿Es niño o niña?’ Las figuras corporales que no caben en ninguno de los géneros caen fuera de lo humano, constituyen el campo de lo deshumanizado y lo abyecto contra lo cual se constituye en sí lo humano" (El género 264).

Revista Iberoamericana, Vol. LXXX, Núm. 247,
ISSN 0034-9631 (Impreso) 
una metáfora más antigua, que tiene reminiscencias de la sífilis: la polución” (103). ${ }^{45}$ A diferencia del cáncer, cuyas metáforas esquivan el problema de la causa, los discursos del sida se tiñen del discurso de la paranoia político-militar al postular que "el enemigo es aquello que causa la enfermedad, un agente infeccioso proveniente del exterior” (104). Los semas de la infección, la invasión, la polución recuerdan las metáforas paranoicas de la Doctrina de la Seguridad Nacional que -con su teoría del enemigo externo ("el comunismo internacional”) invadiendo con su derrame infeccioso el cuerpo (social) propio (articulado en los valores de la civilización occidental y cristiana)- legitimaron la instalación de Estados militarizados en el Cono Sur con sus economías de ajuste. ${ }^{46}$ Los discursos dictatoriales presentaron la ficción de un cuerpo (la Patria) invadido, infectado por valores ajenos, y que necesitaba ser intervenido para extirpar el elemento enfermo. Los textos de Lemebel desarman estas máquinas metafóricas porque dejan de lado las operaciones por semejanza, y reescriben sus materiales en un sistema de relaciones analógicas (de metonimias) que revela una continuidad entre dictadura y sida, como modos análogos de colonización, agentes de “la doble desaparición de casi todas las locas” (Loco 19, énfasis mío): “La plaga nos llegó como una nueva forma de colonización por el contagio" (Loco 9), un dispositivo cómplice del modelo gay "tan penetrativo en su tranza con el poder de la nova masculinidad homosexual” (26). En el cuerpo de las locas “el tufo mortuorio de la dictadura fue un adelanto del sida” (18), y la enfermedad la continuidad de la violencia posindustrial sobre "el plumaje raído de las locas aún torcidas, aún folclóricas en sus ademanes ilegales” (26). Una violencia que en el presente de la escritura continúa desatándose contra las locas, y también sobre los cuerpos de los “péndex” que, como las “sidadas”, dejan el bloque de cemento para ser llevados al nicho del cementerio cuando la violencia de la escena que actúan se da vuelta, cuando se pliega sobre los “ángeles marchitos que siguen entonando la fiesta más allá de los límites permitidos, rompiendo el tímpano oficial con el canto tiznado que regresa a su borde, que se va apagando tragado por las sirenas policiales que encauzan el tránsito juvenil en las púas blindadas del ordenamiento” (Lemebel, La esquina 38).

45 "La transmisión sexual de esta enfermedad, considerada por lo general como una calamidad que uno mismo se ha buscado, merece un juicio mucho más severo que otras vías de transmisión, en particular porque se entiende que el sida es una enfermedad debida no sólo al exceso sexual sino a la perversión sexual" (Sontag, El sida 112).

46 "El discurso del régimen se alimenta, en ese momento, de tres fuentes básicas: 1) la geopolítica de la Doctrina de la Seguridad Nacional -la sociedad chilena sufría una enfermedad y algunas partes de ese cuerpo tenían que ser 'amputadas'; 2) el catolicismo conservador -Chile, en su 'esencia', pertenecía al abanico de naciones occidentales y cristianas; 3) el populismo nacionalista -el pueblo chileno era por naturaleza dócil y amante de la paz. Este complejo ideológico encontró su contrapartida económica en el neoliberalismo monetarista, en la 'libertad' de reestructurar cada rincón de la vida social de acuerdo con la lógica del mercado” (Avelar 37).

Revista Iberoamericana, Vol. LXXX, Núm. 247, Abril-Junio 2014,
ISSN 0034-9631 (Impreso) 
POSDATA

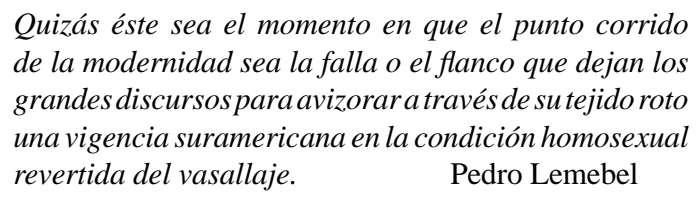

Llegué a la escritura de Pedro Lemebel al encontrarme con sus dos primeros libros de crónicas, y en la lectura apareció, inevitable y despojada, la figura de Pier Paolo Pasolini, "un creador indócil que miró absortamente ciertos signos sociales de su época, en los que fue leyendo los efectos de la progresiva instalación de un neocapitalismo excluyente” (Eltit, "La risa” 41). Pasolini realizó “una operación estética admirable en la que lo desechado y lo castigado por el neocapitalismo (lo subproletariado) adquirió una notable majestuosidad artística cuando se cruzó con los grandes discursos consagrados por la historia” (43). Estas cuestiones están en Lemebel, pero trabajadas de una manera que revela las diferencias posicionales (sociales, pero también estéticas y culturales), como emanaciones de lugares enunciativos diversos. Pasolini fue hacia los márgenes en busca de cuerpos subproletarios, para representar sus pérdidas "como territorio de pureza” (43) con los lenguajes del arte y la alta cultura europea. El régimen del texto de Pasolini es el del arte burgués, porque trabaja con la idea de una verdad estética y registra entonces los conflictos de la autonomía artística que define el punto de partida de su "ir hacia" (su lugar de enunciación). Las crónicas lemebelianas hablan en los márgenes; no van hacia un espacio otro en busca de objetos de representación, escriben (en) los márgenes como el espacio propio en que son producidas, pero que al mismo tiempo es producido por ellas.

En los márgenes se configuran estrategias de lectura, y esta textualidad sigue el movimiento de los modos de leer en los márgenes. La escritura de Lemebel construye significados sobre experiencias de su presente y memorias de otros tiempos, iluminadas con los retazos capturados en la lectura de algunos debates contemporáneos. La productividad textual se conforma atravesada por la economía de los "saberes del pobre”, ${ }^{47}$ y trabaja con los cuerpos subproletarios y travestis leídos en los márgenes, con las legalidades de sus propios espacios-tiempos. Lemebel fue un actor importante en

47 “[...] los saberes de los pobres y marginales, los únicos saberes que poseen quienes, por origen y formación, carecen de Saber. [...] la perspectiva de alguien que no posee saberes prestigiosos (los de las lenguas extranjeras, de la literatura en sus versiones originales, de la cultura tradicional y letrada) y recurre a los saberes callejeros: la literatura en ediciones baratas y traducciones pirateadas, la técnica aprendida en manuales o revistas de divulgación [...]. Prácticas y discursos en busca de una legitimación que, más que competir con los consagrados, crean su propio circuito” (Sarlo, Una modernidad 55-56, énfasis mío).

Revista Iberoamericana, Vol. LXXX, Núm. 247, Abril-Junio 2014, 433-468
ISSN 0034-9631 (Impreso) 
los comienzos de las prácticas estéticas y militantes que ejercieron una nueva partición de lo sensible configurando el campo de la disidencia sexual como espacio estéticopolítico. Este nuevo colectivo construyó sus argumentos trabando una relación (una lectura estratégica) con discursos teóricos producidos en las metrópolis, a través de la cual se familiarizó con debates que leyó con la urgencia de la necesidad militante. El material teórico fue conocido en publicaciones feministas de divulgación, en algunas pocas traducciones, y contadas veces en sus originales. Además, se trataba en la mayoría de los casos de los lenguajes de la crítica universitaria, textos opacos para el activismo de la diversidad que los abordó con la lectura intensa de aquellos fragmentos que provocaban el reconocimiento en la aparición de preceptos y afectos (Deleuze, "Percepto"). Un modo de leer en el que las ideas no se presentan en la forma de conceptos comunicables, aparecen como afecciones y percepciones que remiten el cuerpo lector a su propia experiencia. Lemebel dice reconocer algo de la suya en la lectura de Lacan y Foucault: ${ }^{48}$ su relación con estos textos de la cultura no persigue el sistema conceptual, opera en otro sentido sobre las imantaciones en la lectura que producen preceptos y afectos. El texto de Lemebel hace un valor de este modo de leer convirtiéndolo en una práctica ética que resignifica las carencias, y escribe los cuerpos travestis y subproletarios con las formas de la lectura en los márgenes, como una cadena de imágenes que nombran preceptos y afectos siguiendo la economía metonímica de la pulsión y escurriéndose de la voluntad metafórica (conceptualizante) de la Ley. Esta tropológica es una máquina que produce un texto resistente a la incorporación a los discursos mediáticos y de mercado, y además es la forma que agencia la escritura a la nueva partición de lo sensible. La crónica de Lemebel yuxtapone imágenes (esperpentos) ligadas por su contigüidad, por las mutuas remisiones sintagmáticas que las muestran inacabadas, amputadas, portadoras de la "falla embellecida" por la mirada coliza como huella de lo que se ha caído de la historia oficial, pero también de lo que ha sido dejado de lado por los relatos de la pérdida en las memorias de la izquierda ortodoxa.

\footnotetext{
48 "Cuando me enfrenté por primera vez a estos textos que podríamos llamar "difíciles” como Lacan, Foucault, para mí eran chino, japonés. Pero había algo ahí, un rumor que me interesó. Y había un interés no sólo por entenderlos sino por identificar su proposición de mundo. En esos textos había un sonido desafiante para mí. Y así me di el trabajo de entenderlos y de practicar esas escrituras pero desangrándolas hacia otros territorios ajenos a los de la crítica cultural” (Jeftanovic).
}

Revista Iberoamericana, Vol. LXXX, Núm. 247, Abril-Junio 2014,
ISSN 0034-9631 (Impreso) 
BiBLIOGRAFÍA

Acevedo, Claudio y Eduardo Elgueta, “El discurso homofóbico en la prensa izquierdista durante la Unidad Popular”. Revista Izquierdas II/3 (2008): 1-12.

Augier, Ángel. “Julián del Casal en el contexto del modernismo hispanoamericano”. Julián del Casal. Páginas de vida. Poesía y prosa. Ángel Augier, comp. Caracas: Fundación Biblioteca Ayacucho, 2008. IX-XLVIII.

Avelar, Idelber. Alegorías de la derrota: la ficción posdictatorial y el trabajo de duelo. Santiago de Chile: Cuarto Propio, 2000.

Barthes, Roland. El susurro del lenguaje. Más allá de la palabra y la escritura. Barcelona: Paidós, 1987. “La mitología hoy”. 1971. El susurro del lenguaje. Más allá de la palabra y la escritura. Barcelona: Paidós, 1987. 83-87. Mitologías. 1957. Buenos Aires: Siglo XXI, 2003.

Berman, Marshall. Todo lo sólido se desvanece en el aire. México: Siglo XXI, 1982.

Blanco, Fernando. Deviants, Dissidents, Perverts: Chile Post Pinochet. Columbus, OH: Ohio State U, 2009. <http://etd.ohiolink.edu/send-pdf.cgi/Blanco\%20Fernando. pdf?osu1244262894>. 11 junio 2010.

Blanco, Fernando y Juan. G. Gelpi. "El desliz que desafía otros recorridos. Entrevista con Pedro Lemebel”. Revista Nómada 3 (1997): 3-4.

Butler, Judith. Cuerpos que importan. Buenos Aires, Paidós, 2002. Deshacer el género. Barcelona: Paidós, 2007.

El género en disputa. El feminismo y la subversión de la identidad. Barcelona: Paidós, 2007.

Cangi, Adrián. "Papeles insumisos. Imagen de un pensamiento”. Prólogo a Néstor Perlongher, Papeles insumisos. Adrián Cangi y Reynaldo Jiménez, eds. Buenos Aires: Santiago Arcos, 2004. 7-32.

y Paula Siganevich (comps.) Lúmpenes Peregrinaciones. Ensayos sobre Néstor Perlongher. Rosario: Beatriz Viterbo, 1996.

Casal, Julián del. “El matadero”. 1890. Páginas de vida. Poesía y prosa. Ángel Augier, comp. Caracas: Fundación Biblioteca Ayacucho, 2008. 320-322.

Páginas de vida. Poesía y prosa. Ángel Augier, comp. Caracas: Fundación Biblioteca Ayacucho, 2008.

Cella, Susana. “Figuras y nombres”. Adrián Cangi y Paula Siganevich, comps. Lúmpenes Peregrinaciones. Ensayos sobre Néstor Perlongher. Rosario: Beatriz Viterbo, 1996.

Deleuze, Gilles. Crítica y clínica. Barcelona: Anagrama, 1996. El pliegue. Leibniz y el Barroco. Buenos Aires: Paidós, 2005. y Félix Guattari. "Percepto, afecto, concepto”. Qu’ est-ce que la philosophie? Alejandro Palermo, trad. Paris: Minuit, 1991. 154-188.

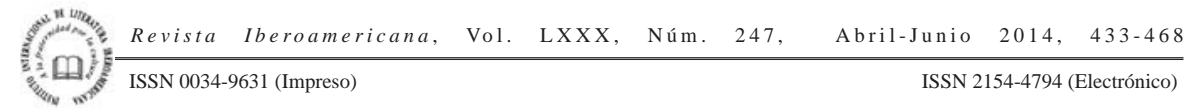


Derrida, Jacques. “Firma, acontecimiento, contexto”. Márgenes de la filosofía, Madrid: Cátedra, 1993.

Dubet, François. "Las conductas marginales de los jóvenes pobladores”. Proposiciones. Marginalidad, movimientos sociales y democracia. Santiago de Chile: Ediciones Sur, 1987. 94-100.

Eltit, Diamela. Emergencias. Escritos sobre literatura, arte y política. Santiago de Chile: Planeta, 2000.

"La compra, la venta”. Emergencias. Escritos sobre literatura, arte y política. Santiago de Chile: Planeta, 2000. 24-27.

"La risa impura". Emergencias. Escritos sobre literatura, arte y política. Santiago de Chile: Plantea, 2000. 41-46.

"Las dos caras de la moneda". 1997. Emergencias. Escritos sobre literatura, arte y política. Santiago de Chile: Planeta, 2000. 17-24.

Eribon, Didier. Reflexiones sobre la cuestión gay. Barcelona: Anagrama, 2001

Garretón, Manuel Antonio. Hacia una nueva era política. Estudio sobre las democratizaciones. Santiago de Chile: Fondo de Cultura Económica, 1995.

González Echevarría, Roberto. Relecturas. Estudios sobre literatura cubana. Caracas: Monte Ávila, 1976.

Halperín Donghi, Tulio. Historia contemporánea de América Latina. Buenos Aires: Fondo de Cultura Económica, 1992.

Harvey, David. "El neoliberalismo como destrucción creativa". The ANNALS of the American Academy of Political and Social Science. Germán Leyens, trad. 2007.

Jeftanovic, Andrea. “Pedro Lemebel: el cronista de los márgenes”. <www.letras.s5.com/ lemebel150.htm>. 8 junio 2010.

Kristeva, Julia. La revolution du langage poétique. Paris: du Seuil, 1974. Poderes de la perversión. México: Siglo XXI, 1989.

Lemebel, Pedro. De perlas y cicatrices. Santiago de Chile: LOM, 1998. La esquina es mi corazón. Crónica urbana. 1995. Santiago de Chile: Cuarto Propio, 1997. Loco afán. Crónicas del sidario. 1996. Barcelona: Anagrama: 2000.

López García, Isabelle. "Entrevista a Pedro Lemebel, 22 de octubre de 2004”. La question du genre dans les chroniques de Pedro Lemebel. Thèse pour obtener le grade de docteur de l'Université de Paris - Sorbonne Paris IV. Paris: Université de Paris-Sorbonne Paris IV, 2007.

Ludmer, Josefina. Aquí América Latina. Una especulación. Buenos Aires: Eterna Cadencia, 2010.

Martí, José. Nuestra América. Caracas: Biblioteca Ayacucho, 1977. “Un viaje a Venezuela”. Nuestra América. Caracas: Biblioteca Ayacucho, 1977. 227-239.

Revista Iberoamericana, Vol. LXXX, Núm. 247, Abril-Junio 2014, $433-468$
ISSN 0034-9631 (Impreso) 
Molloy, Sylvia. Acto de presencia. La escritura autobiográfica en Hispanoamérica. México: El Colegio de México - FCE, 1986.

Montaldo, Graciela. La sensibilidad amenazda. Rosario: Beatriz Viterbo, 1994.

Morán, Francisco. Julián del Casal o los pliegues del deseo. Madrid: Verbum, 2008.

Muñoz, Leopoldo. "La invasión neoliberal en Chile”.2002. ARCHIVO CHILE, Web del Centro de Estudios "Miguel Enríquez” (CEME), <www.archivo-chile.com>. 25 abril 2010.

Panesi, Jorge. Críticas. Buenos Aires: Norma, 2000. "Detritus”. Críticas. Buenos Aires: Norma, 2000. 303-328.

"Marginales en la noche”. Críticas. Buenos Aires: Norma, 2000. 339-353.

Perlongher, Néstor. “Caribe transplatino”. Prosa plebeya. Ensayos 1980-1992. Christian Ferrer y Osavaldo Baigorria, eds. Buenos Aires: Colihue, 1997. 93-102. “El neobarroco y la revolución”. Papeles insumisos. Adrián Cangi y Reynaldo Jiménez, eds. Buenos Aires: Santiago Arcos, 2004. 235-246. "El orden de los cuerpos". Prosa plebeya. Ensayos 1980-1992. Christian Ferrer y Osavaldo Baigorria, eds. Buenos Aires: Colihue, 1997. 43-44. "La desaparición de la homosexualidad”. Prosa plebeya. Ensayos 1980-1992. Christian Ferrer y Osavaldo Baigorria, eds. Buenos Aires: Colihue, 1997. 85-90. La prostitución masculina. Buenos Aires: Ediciones de la Urraca, 1993. "Los devenires minoritarios". Prosa plebeya. Ensayos 1980-1992. Christian Ferrer y Osavaldo Baigorria, eds. Buenos Aires: Colihue, 1997. 65-75. "Nuevas escrituras transplatinas". Papeles insumisos. Adrián Cangi y Reynaldo Jiménez, eds. Buenos Aires: Santiago Arcos, 2004. 241-246. O Negócio do Michê. Prostituição Viril em São Paulo. São Paulo: Ed. Brasiliense, 1987.

Papeles insumisos. Adrián Cangi y Reynaldo Jiménez, eds. Buenos Aires: Santiago Arcos, 2004.

Prosa plebeya. Ensayos 1980-1992. Christian Ferrer y Osavaldo Baigorria, eds. Buenos Aires: Colihue, 1997.

Power, Margaret. “La Unidad Popular y la masculinidad”. La ventana 6(1997): 250-270.

Ramos, Julio. Desencuentros de la modernidad en América Latina. México: Fondo de Cultura Económica, 1989.

Rancière, Jacques. "La política de la estética”. Otra parte. Revista de letras y artes 9 (2006): 12-18.

Richard, Nelly. “Destrucción, reconstrucción y deconstrucción”. Fracturas de la memoria. Arte y pensamiento crítico. Buenos Aires: Siglo XXI, 2007. 29-39.

Fracturas de la memoria. Arte y pensamiento crítico. Buenos Aires: Siglo XXI, 2007.

"La cita de la violencia: rutina oficial y convulsiones del sentido". Fracturas de la memoria. Arte y pensamiento crítico. Buenos Aires: Siglo XXI, 2007. 133-151.

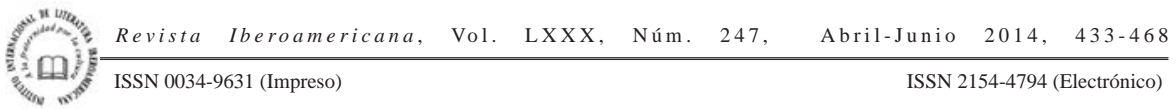


"La historia contándose y la memoria contada: el contratiempo crítico de la memoria”. Fracturas de la memoria. Arte y pensamiento crítico. Buenos Aires: Siglo XXI, 2007. 197-211.

"La problemática del feminismo en los años de la transición en Chile”. La insubordinación de los signos; cambio político, transformaciones culturales y poéticas de la crisis. Santiago de Chile: Cuarto Propio, 1994. 227-239.

“Las marcas del destrozo y su reconjugación en plural”. Fracturas de la memoria. Arte y pensamiento crítico. Buenos Aires: Siglo XXI, 2007. 169-183.

"Márgenes e instituciones: la Escena de Avanzada”. Fracturas de la memoria. Arte y pensamiento crítico. Buenos Aires: Siglo XXI, 2007. 13-28.

“Memoria, fotografía y desaparición: drama y tramas". Punto de vista XIII/68 (2000): 29-33.

"Periferias culturales y descentramientos posmodernos (marginalidad latinoamericana y recomposición de los márgenes)”. Punto de vista XIV/40 (1991): 5-7.

“Roturas, enlaces y discontinuidades”.Fracturas de la memoria.Arteypensamiento crítico. Buenos Aires: Siglo XXI, 2007. 109-132.

Robles, Víctor Hugo. “La primer protesta homosexual en Chile: Stonewall Criollo”. El Ciudadano III/48 (2007): 3-5.

Said, Edward. Beginnings: Intention and Method. Nueva York: Columbia UP, 1985. Orientalismo. Barcelona: Random House - Mondadori, 2003.

Salazar, Gonzalo, "Políticas queer y capitalismo: revoluciones moleculares en el Chile posdictatorial”. Revista Sociedad\&Equidad 1 (2011): 1-8.

Sarduy, Severo. "El barroco y el neobarroco". América Latina en su literatura. César Fernández Moreno, coordinador. México: Siglo XXI, 1984. 167-184.

“Un heredero”. José Lezama Lima. Paradiso. Colección Archivos. Cintio Vitier, coord. Naterre, France: ALLCA XX, 1996. 590-597.

Sarlo, Beatriz. “Cuando la política era joven”. Punto de vista XX/58 (1997): 15-19. "El relativismo absoluto o cómo el mercado y la sociología reflexionan sobre la estética”. Punto de vista XVII/48 (1994): 27-31.

Tiempo pasado. Cultura de la memoria y giro subjetivo. Una discusión. Buenos Aires: Siglo XXI, 2005.

Una modernidad periférica: Buenos Aires 1920-1930. 1988. Buenos Aires: Nueva Visión, 1996.

Sontag, Susan. La enfermedad y sus metáforas. El sida y sus metáforas. Buenos Aires: Taurus, 2005.

Valle-Inclán, Ramón del. Luces de Bohemia. Obras completas. Madrid: Espasa, 1954.

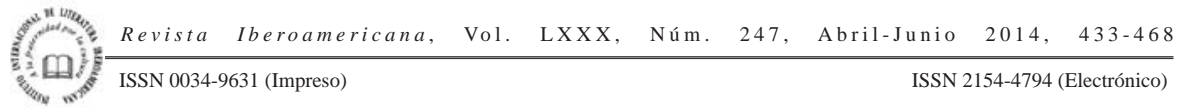

